\title{
The neuroprotective effects of human bone marrow mesenchymal stem cells are dose-dependent in TNBS colitis
}

\author{
Ainsley M. Robinson ${ }^{\dagger}$, Ahmed A. Rahman ${ }^{\dagger}$, Sarah Miller, Rhian Stavely, Samy Sakkal and Kulmira Nurgali ${ }^{*}$
}

\begin{abstract}
Background: The incidence of inflammatory bowel diseases (IBD) is increasing worldwide with patients experiencing severe impacts on their quality of life. It is well accepted that intestinal inflammation associates with extensive damage to the enteric nervous system (ENS), which intrinsically innervates the gastrointestinal tract and regulates all gut functions. Hence, treatments targeting the enteric neurons are plausible for alleviating IBD and associated complications. Mesenchymal stem cells (MSCs) are gaining wide recognition as a potential therapy for many diseases due to their immunomodulatory and neuroprotective qualities. However, there is a large discrepancy regarding appropriate cell doses used in both clinical trials and experimental models of disease. We have previously demonstrated that human bone marrow MSCs exhibit neuroprotective and anti-inflammatory effects in a guinea-pig model of 2,4,6-trinitrobenzene-sulfonate (TNBS)-induced colitis; but an investigation into whether this response is dose-dependent has not been conducted.

Methods: Hartley guinea-pigs were administered TNBS or sham treatment intra-rectally. Animals in the MSC treatment groups received either $1 \times 10^{5}, 1 \times 10^{6}$ or $3 \times 10^{6} \mathrm{MSCs}$ by enema 3 hours after induction of colitis. Colon tissues were collected 72 hours after TNBS administration to assess the effects of MSC treatments on the level of inflammation and damage to the ENS by immunohistochemical and histological analyses.

Results: MSCs administered at a low dose, $1 \times 10^{5}$ cells, had little or no effect on the level of immune cell infiltrate and damage to the colonic innervation was similar to the TNBS group. Treatment with $1 \times 10^{6} \mathrm{MSC}$ decreased the quantity of immune infiltrate and damage to nerve processes in the colonic wall, prevented myenteric neuronal loss and changes in neuronal subpopulations. Treatment with $3 \times 10^{6} \mathrm{MSC}$ had similar effects to $1 \times 10^{6} \mathrm{MSC}$ treatments.

Conclusions: The neuroprotective effect of MSCs in TNBS colitis is dose-dependent. Increasing doses higher than $1 \times 10^{6}$ MSCs demonstrates no further therapeutic benefit than $1 \times 10^{6}$ MSCs in preventing enteric neuropathy associated with intestinal inflammation. Furthermore, we have established an optimal dose of MSCs for future studies investigating intestinal inflammation, the enteric neurons and stem cell therapy in this model.
\end{abstract}

Keywords: Inflammatory bowel disease, Intestinal inflammation, Mesenchymal stem cells, Enteric neurons, Dose-dependence

\footnotetext{
* Correspondence: kulmira.nurgali@vu.edu.au

${ }^{\dagger}$ Equal contributors

College of Health and Biomedicine, Victoria University, Melbourne, VIC,

Australia
} 


\section{Background}

Crohn's disease and ulcerative colitis are idiopathic inflammatory bowel diseases (IBD) characterized by chronic relapsing inflammation of the gastrointestinal (GI) tract [1]. Crohn's disease manifests mostly in the ileum and colon, but can affect any region of the GI tract. Inflammation is discontinuous, focal and transmural progressing to the development of fistulas, abscesses, and strictures [2]. In contrast, ulcerative colitis is characterized by colonic mucosal inflammation extending proximally from the rectum [3]. Fundamental symptoms reported by IBD patients include abdominal pain, diarrhea, bloody stools, fecal urgency and rectal bleeding, as well as systemic symptoms of weight loss, fever, and fatigue $[4,5]$. Furthermore, the risk of colorectal cancer increases as a complication of IBD [6].

The incidence of IBD is an evolving global concern, highest in westernized nations, such as Canada, Australia and countries in northern Europe, and increasing in developing nations in conjunction with their industrialization [7]. The peak age for IBD onset is 15 to 40 years and although not generally associated with mortality, the relentlessness of the disease negatively impacts on the patient's quality of life [8]. Furthermore, both direct and indirect expenditures of IBD are substantial economic burdens on healthcare systems worldwide [9]. Conventional therapy for IBD includes anti-inflammatory drugs, corticosteroids, biologics, antimicrobial therapy and immunomodulators, which aim to treat symptoms rather than the underlying pathological mechanisms of the disease. Furthermore, these medications demonstrate long-term toxicity and/or failure to induce and maintain remission [10-12].

Abnormalities in the enteric nervous system (ENS) have been suggested to play a role in IBD pathogenesis for more than 50 years [13]. Comprising a complex network of neurons and glial cells embedded in the gut wall, the ENS intrinsically innervates the GI tract and is responsible for regulating and coordinating gut functions independently of the central nervous system [14]. Results from clinical and experimental models of IBD have reliably demonstrated enteric neuronal loss, axonal degeneration, glial cell hyperplasia, neuronal hyperexcitability and altered neurotransmission associated with intestinal inflammation [15-22]. Inflammationinduced changes to the neurochemical coding of myenteric neurons, specifically cholinergic and nitrergic subpopulations, disrupt GI functions and intestinal motility [23-25]. Furthermore, structural and functional alterations to the ENS persist beyond the resolution of active inflammation [26, 27]. These findings suggest that inflammation-induced insults to the ENS are integral in the generation of IBD symptoms and that the disease severity may be reduced via therapeutic strategies targeting the enteric neurons.
Due to unique therapeutic characteristics, mesenchymal stem cells (MSCs) have emerged as exciting candidates for cellular therapy against a range of immune-mediated and neurodegenerative disorders, including IBD [28-32]. Accumulating evidence has revealed that the protective mechanisms and endogenous regeneration initiated by MSCs are attributable to their capacity to produce and release an array of bioactive soluble factors acting in a paracrine manner to directly stimulate target cells and/or provoke nearby cells to emit functionally active mediators [33-35]. Further potential advantages of MSCs for cellular therapy include: in vitro expansion capacity, ease of isolation from adult tissue sources, low immunogenicity, capability for in vitro genetic modification and a safe and feasible profile for transplantation into humans [36-38].

While many studies report the effectiveness of MSC treatments in attenuating the mechanisms of disease, some MSC therapies are reported as being ineffective or only demonstrating short-term effectiveness [39-42]. Various factors, including cellular dose and timing of administration of MSCs, influence therapeutic efficacy of these cells [43]. Hence, it was suggested different doses of MSCs might have distinct immune or protective effects [44]. There is great variation among clinical trials and experimental models of disease in the injected dosage of MSCs [45, 46], suggesting that MSCs can effectively treat diseases in a dose-dependent manner [47-51]. In addition, defining an optimal MSC dose for both preclinical and clinical studies extends to benefits such as reduced production costs, less tissue required for MSC expansion, a lower chance of MSC mutation and a reduced likelihood of MSC accumulation in the filtering organs.

While it has been confirmed that MSCs migrate to sites of intestinal inflammation where they assist in the restoration and repair of the epithelial barrier and damaged tissue via anti-inflammatory actions [51-55], there are only a few studies examining the effects of MSC-based therapies in attenuating inflammationinduced enteric neuropathy $[25,35,56,57]$. In these studies, it was concluded that locally applied bone marrow (BM)-MSCs administered at a dose of $1 \times 10^{6}$ are neuroprotective towards enteric neurons compromised by 2,4,6-trinitrobenzene-sulfonate (TNBS)-induced inflammation $[25,35,57]$. These results provide the foundation for examining the neuroprotective potential of MSC therapy in intestinal inflammation. However, no studies have investigated the dose-response relationship of MSCs in protecting enteric neurons from damage and/or death induced by colitis. Therefore, the aim of this study was to investigate at which dose $\left(1 \times 10^{5}, 1 \times 10^{6}\right.$ or $3 \times 10^{6}$ ) human BM-MSCs are most beneficial in protecting and repairing enteric neurons following induction of colitis. This knowledge will define the optimal 
MSC dosage for treatment of enteric neuropathy associated with TNBS-induced inflammation in a guinea-pig model of colitis, as well as contribute towards future investigations into the mechanisms of MSC-stimulated enteric neuroprotection.

\section{Methods}

\section{Animals}

Male and female Hartley guinea-pigs weighing 140-280 g were obtained from South Australian Health and Medical Research Institute (SAHMRI, Adelaide, SA, Australia) and randomly assigned to experimental groups. All animals were housed in a temperature-controlled environment with 12-hour day/night cycles and had ad libitum access to food and water. All animal experiments in this study complied with the guidelines of the National Health and Medical Research Council (NHMRC) Australian Code of Practice for the Care and Use of Animals for Scientific Purposes under approval of the Victoria University Animal Experimentation Ethics Committee (approval number AEETH 12-012). All efforts were made to minimize animal suffering.

\section{Cell culture and passaging}

MSCs derived from human BM-MSC cell lines BM-7025 and BM-7081 (Tulane University, New Orleans, LA, USA) were plated at an initial density of 60 cells $/ \mathrm{cm}^{2}$ and incubated in complete culture medium (minimum essential medium $(\alpha-\mathrm{MEM})$ supplemented with $16.5 \%$ MSCqualified fetal bovine serum (FBS), $100 \mathrm{U} / \mathrm{mL}$ penicillin/ streptomycin, and 100X GlutaMAX) (all purchased from Gibco, Life Technologies, Mulgrave, VIC, Australia) at $37{ }^{\circ} \mathrm{C}$. Expansion medium was replenished every $48-72$ hours for $10-14$ days until the cells were $70-85 \%$ confluent (maximum). MSCs were rinsed in $5 \mathrm{~mL}$ sterile phosphate-buffered solution (PBS) prior to incubation with $3 \mathrm{~mL}$ TrypLE Select (Gibco, Life Technologies, Mulgrave, VIC, Australia) for 3 minutes at $37{ }^{\circ} \mathrm{C}$ to detach cells. Enzymatic activity was neutralized by $8 \mathrm{~mL}$ of stop solution $(\alpha-\mathrm{MEM}+5 \% \mathrm{FBS})$ and MSCs were collected and centrifuged at $450 \mathrm{~g}$ for 5 minutes at room temperature. Cells were then resuspended in fresh culture medium and counted using a haemocytometer under a light microscope.

\section{MSC characterization}

MSCs were cultured to the fourth passage for all experiments and characterized for their expression of surface antigens, differentiation potential, and colony-forming ability as previously described $[25,57]$. All MSCs utilized in this study met criteria for defining in vitro human MSC cultures proposed by the International Society for Cellular Therapy (ISCT) [58].

\section{Induction of colitis}

For the induction of colitis, TNBS (Sigma-Aldrich, Castle Hill, NSW, Australia) was dissolved in 30\% ethanol to a concentration of $30 \mathrm{mg} / \mathrm{kg}$ and administered intra-rectally $7 \mathrm{~cm}$ proximal to the anus (total volume of $300 \mu \mathrm{L}$ ) by a lubricated silicone catheter [21]. For TNBS administration, guinea-pigs were anaesthetized with isoflurane $\left(1-4 \%\right.$ in $\left.\mathrm{O}_{2}\right)$ during the procedure. Shamtreated guinea-pigs underwent the same procedure without administration of TNBS.

\section{MSC treatments}

Guinea-pigs in the MSC-treated groups were anaesthetized with isoflurane 3 hours after TNBS administration and administered MSC therapies by enema into the colon via a silicone catheter. MSCs were administered at a dose of $1 \times 10^{5}, 1 \times 10^{6}$ or $3 \times 10^{6}$ cells in $300 \mu \mathrm{L}$ of sterile PBS. The peak of ethanol-induced epithelial damage occurs at 3 hours in TNBS-induced colitis [59], therefore this time point was selected for the administration of MSCs. Animals were held at an inverted angle following MSC treatments to prevent leakage from the rectum and were weighed and monitored daily following treatment. Guinea-pigs were culled via stunning and exsanguination 72 hours after TNBS administration [20]. Sections of the distal colon were collected for histological and immunohistochemical studies.

\section{Tissue preparation}

Following dissection, tissues were immediately placed in oxygenated PBS (0.1 M, pH 7.2) containing an L-type $\mathrm{Ca}^{2+}$ channel blocker, nicardipine $(3 \mu \mathrm{m})$ (Sigma-Aldrich, Castle Hill, NSW, Australia), to inhibit smooth muscle contraction. Tissues were cut open along the mesenteric border and then processed for whole-mount longitudinal muscle-myenteric plexus (LMMP) preparations and cross sections.

\section{LMMP preparations}

Colon tissues were pinned flat with the mucosal side up and stretched to maximal capacity without tearing in a Sylgard-lined Petri dish. Tissues were fixed overnight at $4{ }^{\circ} \mathrm{C}$ in Zamboni's fixative (2\% formaldehyde and $0.2 \%$ picric acid) and subsequently washed for $3 \times 10$ minutes in dimethyl sulfoxide (DMSO) (Sigma-Aldrich, Castle Hill, NSW, Australia) followed by $3 \times 10$ minutes in $0.1 \mathrm{M}$ PBS to remove fixative. Zamboni's fixative was chosen for tissue fixation to minimize neural tissue autofluorescence. Distal colon samples were dissected to expose the myenteric plexus by removing the mucosa, submucosa and circular muscle layers prior to immunohistochemistry. 


\section{Cross sections}

Tissues for cross sections were pinned with the mucosal side up in a Sylgard-lined Petri dish, without stretching. Tissues for immunohistochemistry were fixed as described above and subsequently frozen in liquid nitrogen-cooled isopentane and optimum cutting temperature (OCT) compound (Tissue-Tek, Torrance, CA, USA). Samples were stored at $-80{ }^{\circ} \mathrm{C}$ until they were cryosectioned $(30 \mu \mathrm{m})$ onto glass slides for immunohistochemistry. Tissues for histology were fixed in $10 \%$ buffered formalin overnight at $4{ }^{\circ} \mathrm{C}$ and stored in $70 \%$ ethanol until paraffin embedding.

\section{Immunohistochemistry}

Immunohistochemistry was performed on whole-mount LMMP preparations and cross sections of the distal colon as previously described [25, 35]. After a 1-hour incubation in 10\% normal donkey serum (NDS) (Merck Millipore, Melbourne, VIC, Australia) diluted in $0.1 \mathrm{M}$ PBS-0.1\% Triton X-100 at room temperature, the samples were washed with $0.1 \mathrm{M}$ PBS-0.1\% Triton X-100 $(2 \times 5$ minutes $)$ and incubated with primary antibodies (Table 1) diluted in 2\% NDS and 0.1 M PBS-0.1\% Triton $\mathrm{X}-100$ overnight at room temperature. Tissues were then washed in $0.1 \mathrm{M}$ PBS- $0.1 \%$ Triton X-100 $(2 \times 5$ minutes $)$ prior to incubation with secondary antibodies (Table 1) (diluted in 2\% NDS and 0.1 M PBS-0.1\% Triton X-100) for 2 hours at room temperature. Following $3 \times 10$ minutes washes in $0.1 \mathrm{M}$ PBS-0.1\% Triton X-100, LMMP preparations were mounted on glass slides with fluorescent mounting medium (DAKO, North Sydney, NSW, Australia).

\section{Histology}

After fixation, tissues were paraffin embedded, sectioned at $5 \mu \mathrm{m}$, deparaffinized, cleared, and rehydrated in graded ethanol concentrations. For standard haematoxylin and eosin (H\&E) staining, sections were immersed in xylene ( $3 \times 4$ minutes), $100 \%$ ethanol (3 minutes), $90 \%$ ethanol, ( 2 minutes), $70 \%$ ethanol (2 minutes), rinsed in tap water, haematoxylin (4 minutes), rinsed in tap water, Scott's tap water (1 minute), eosin (3 minutes), rinsed in tap water, $100 \%$ ethanol $(2 \times 1$ minute $)$, xylene $(2 \times 3 \mathrm{mi}-$ nutes) and mounted on glass slides with distrene plasticizer xylene (DPX) mountant.

\section{Imaging}

Confocal microscopy was undertaken on an Eclipse $\mathrm{Ti}$ confocal laser scanning system (Nikon, Tokyo, Japan). Fluorophores were visualized by using a $488 \mathrm{~nm}$ excitation filter for FITC and a $559 \mathrm{~nm}$ excitation filter for Alexa 594. Z-series images were acquired at a nominal thickness of $0.5 \mu \mathrm{m}(512 \times 512$ pixels) with $\times 20$ (dry, 0.75 ) or $\times 40$ (oil immersion, 1.3) lenses. H\&E-stained colon sections were visualized using an Olympus BX53 microscope (Olympus, Notting Hill, VIC, Australia) and images were captured with CellSense ${ }^{\mathrm{TM}}$ software.

\section{Quantitative analyses of immunohistochemical and histological data}

In whole-mount LMMP preparations, the total number of myenteric neurons immunoreactive (IR) for $\mathrm{Hu}$, neuronal nitric oxide synthase (nNOS) and choline acetyltransferase (ChAT) were counted within eight randomly

Table 1 Antibodies used in this study

\begin{tabular}{|c|c|c|c|c|}
\hline & Host species & Dilution & Supplier & Application in this study \\
\hline \multicolumn{5}{|l|}{ Primary antibodies } \\
\hline Anti- $\beta$-Tubulin class III & Rabbit & $1: 1000$ & Abcam, Melbourne, VIC, Australia & Cross sections \\
\hline Anti-CD45 (clone $\mathrm{IH}-1)$ & Mouse & $1: 200$ & Abcam, Melbourne, VIC, Australia & Cross sections \\
\hline Anti-choline acetyltransferase (ChAT) & Goat & $1: 500$ & Merck Millipore, Bayswater, Australia & LMMP preparations \\
\hline Anti-Hu (clone 15A7.1) & Mouse & $1: 500$ & Merck Millipore, Bayswater, VIC, Australia & LMMP preparations \\
\hline Anti-neuronal nitric oxide synthase (nNOS) & Goat & $1: 500$ & Novus Biologicals, Littleton, CO, USA & LMMP preparations \\
\hline $\begin{array}{l}\text { Anti-human leucocyte antigen } \\
(H L A)-A, B, C \text { (conjugated to fluorescein } \\
\text { isothiocyanate (FITC)) }\end{array}$ & Human & $1: 50$ & BioLegend, San Diego, CA, USA & Cross sections \\
\hline \multicolumn{5}{|l|}{ Secondary antibodies } \\
\hline Alexa Fluor 594 & Donkey anti-mouse & $1: 200$ & $\begin{array}{l}\text { Jackson Immunoresearch Labs, } \\
\text { West Grove, PA, USA }\end{array}$ & LMMP preparations \\
\hline Alexa Fluor 594 & Donkey anti-rabbit & $1: 200$ & $\begin{array}{l}\text { Jackson Immunoresearch Labs, } \\
\text { West Grove, PA, USA }\end{array}$ & Cross sections \\
\hline FITC 488 & Donkey anti-goat & $1: 200$ & $\begin{array}{l}\text { Jackson Immunoresearch Labs, } \\
\text { West Grove, PA, USA }\end{array}$ & LMMP preparations \\
\hline FITC 488 & Donkey anti-mouse & $1: 200$ & $\begin{array}{l}\text { Jackson Immunoresearch Labs, } \\
\text { West Grove, PA, USA }\end{array}$ & Cross sections \\
\hline
\end{tabular}


captured images per preparation at $\times 20$ magnification (total area $2 \mathrm{~mm}^{2}$ ), as well as per ganglia (average of ten ganglia per animal). Infiltration of leucocytes throughout the colon wall was assessed by counting the total number of CD45-IR cells within the mucosa and muscle layers in cross sections (total area $1.5 \mathrm{~mm}^{2}$ ). The density of nerve fibres was determined by measuring $\beta$-tubulin (III)-IR in eight randomly captured images at $\times 20$ magnification. All images were captured under identical acquisition exposure time conditions and calibrated to standardized minimum baseline fluorescence. Images were converted from red, green, and blue (RGB) to grayscale 8 bit then to binary; changes in fluorescence from the baseline were measured using Image J software (National Institutes of Health, Bethesda, MD, USA). The area of immunoreactivity was then expressed as a percentage of the total area examined. Gross morphological damage in H\&E-stained colon sections was assessed by histological grading of four parameters: mucosal flattening $(0=$ normal, $3=$ severe flattening), occurrence of haemorrhagic sites $(0=$ none, $3=$ frequent sites), loss of goblet cells $(0=$ normal, $3=$ severe loss of cells $)$ and variation of the circular muscle $(0=$ normal, $3=$ considerable thickening of muscular layer) [25]. Quantitative analyses were conducted blindly.

\section{Statistical analysis}

Statistical differences were determined by Student's $t$ test (two-tailed) or one-way ANOVA with Bonferroni post hoc test for multiple group comparisons using Prism v6.0 (Graphpad Software Inc., La Jolla, CA, USA). Data were considered statistically significant when $P<0.05$. Data were presented as mean \pm standard error of the mean (SEM), if not specified otherwise.

\section{Results}

MSCs migration and engraftment at the site of inflammation The capacity of MSCs to migrate and engraft to the area of tissue damage and inflammation was assessed in sections of the distal colon from guinea-pigs treated with $1 \times 10^{5}, 1 \times 10^{6}$ or $3 \times 10^{6}$ MSCs administered by enema 3 hours after the induction of TNBS colitis. Transmural migration of MSCs within colon cross sections was identified by labelling with an antibody against human leucocyte antigen (HLA)-A,B,C, which detects major histocompatibility complex class I (MHC class I) antigens expressed by all human nucleated cells (Fig. 1). MSCs successfully engrafted into the intestinal wall evident by localization of HLA-A,B,C-positive cells in the colon sections collected at 72 hours post induction of colitis (Fig. 1a-c). HLA-A,B,C-positive cells were present mostly in the mucosal lamina propria in colon sections from guinea-pigs treated with $1 \times 10^{5} \mathrm{MSCs}$ (Fig. 1a). When administered at higher doses $\left(1 \times 10^{6}\right.$ and $\left.3 \times 10^{6}\right)$, transmural migration and engraftment of human MSCs into the colon wall to the level of the myenteric ganglia was evident (Fig. 1b-c).

\section{Effects of MSC treatment on tissue repair}

Changes to the colonic architecture 72 hours after induction of TNBS-induced colitis were evaluated by gross morphological assessment of H\&E-stained colon sections (Fig. 2). Continuous epithelial cell lining, regular structural arrangements of goblet cells and crypts and defined colonic layers were evident in H\&E-stained colon cross sections from sham-treated guinea-pigs (histological score 0-1) (Fig. 2a). In contrast, sections from guinea-pigs in the TNBS-only group displayed disruptions to the epithelial lining, goblet cell loss, glandular distortion and flattening of crypts (histological score 2) (Fig. 2b). Sections from animals in all MSCtreated groups revealed accelerated healing of the mucosa and repair to levels comparable with sham-treated guineapigs (histological score $0-1$ for all) (Fig. 2c-e).

\section{Dose-dependent effects of MSC treatments on leucocyte infiltration in the inflamed colon}

The severity of colitis and the anti-inflammatory effect of MSC treatments were assessed by quantitative

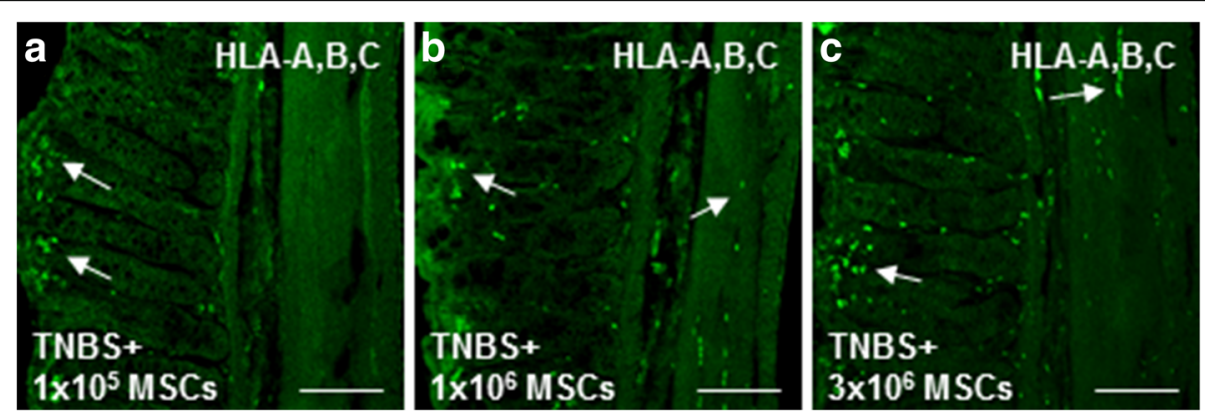

Fig. 1 MSC homing within the inflamed colon. The migration and engraftment of MSCs (white arrows) to the site of TNBS-induced inflammation in sections of the guinea-pig colon was confirmed using anti-HLA-A,B,C antibody specific to human MHC class I at 72 hours post induction of colitis (a-c). Scale bars $=100 \mu \mathrm{m}, n=4 /$ group/time point. HLA-A,B,C human leucocyte antigen, IR immunoreactive, MSCs mesenchymal stem cells, TNBS 2,4,6-trinitrobenzene sulfonic acid 


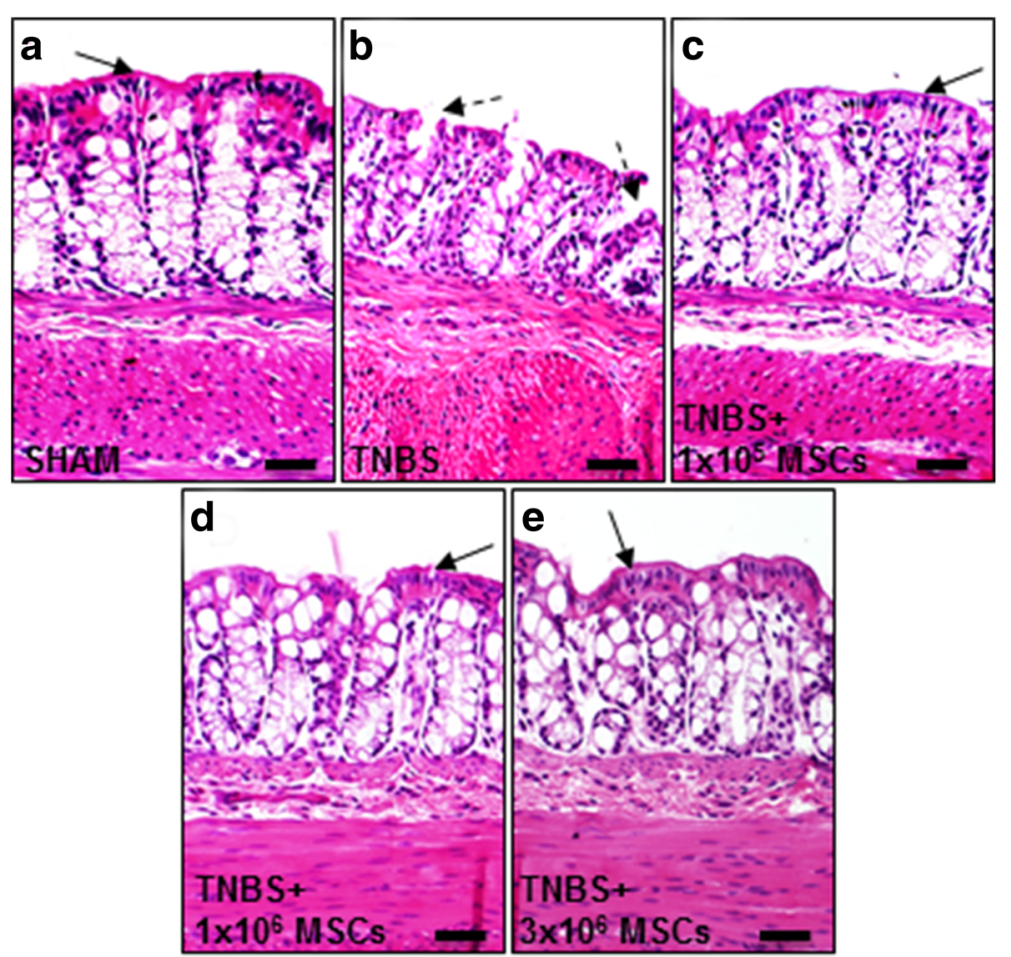

Fig. 2 Gross morphological changes in the distal colon assessed in H\&E-stained cross sections. A complete and continuous epithelial lining (black arrows) and regular arrangement of colonic layers was apparent in sections from sham-treated animals (a). Flattening of the glands, disruption to the epithelial lining (dotted black arrows) and goblet cell loss were evident in sections from TNBS-administered guinea-pigs at 72 hours post induction of colitis (b). H\&E-stained sections from $1 \times 10^{5}, 1 \times 10^{6}$ and $3 \times 10^{6} \mathrm{MSC}$-treated animals revealed accelerated repair and restoration of the colonic architecture (c-e). Scale bars $=50 \mu \mathrm{m}, n=4$ /group/time point. MSCS mesenchymal stem cells, TNBS 2,4,6-trinitrobenzene sulfonic acid

analyses of CD45+ leucocytes in colon cross sections (Fig. 3). TNBS administration produced an increase in leucocytes within the mucosa and muscular layers at 72 hours when compared to sections from sham-treated guinea-pigs (mucosa: $P<0.001$ and muscle: $P<0.001$ ) (Table 2, Fig. 3a-b, f-g). The TNBS-induced increase in number of leucocytes in the mucosa and muscular layers was reduced by all MSC treatments compared to the TNBS-only group $(P<0.001$ for all). However, leucocyte numbers in both the mucosa and muscular layers of $1 \times$ $10^{5}$ MSC-treated animals were higher compared to sham-treated, $1 \times 10^{6}$ MSC-treated and $3 \times 10^{6}$ MSCtreated guinea-pigs $(P<0.001$ for all $)$ (Table 2, Fig. 3a-g).

\section{Dose-dependent effects of MSC treatment on nerve fibre regrowth and enteric neuroprotection}

Nerve fibres innervating smooth muscles and mucosa were identified in cross sections of the guinea-pig distal colon by labelling with an antibody specific to neuronal microtubule protein $\beta$-tubulin (III) (Fig. 4). Regularly distributed $\beta$-tubulin (III)-IR fibres were observed within the mucosal gland cores, submucosal and muscular layers of colon sections from sham-treated guinea-pigs (Fig. 4a). Following TNBS administration, $\beta$-tubulin (III)-IR fibres within the mucosa were disordered, patchy, and arranged irregularly (Fig. 4b). Quantitative analysis confirmed a reduction in $\beta$-tubulin (III)-IR fibre density in both mucosa $(P<0.001)$ and muscle $(P<0.001)$ layers of the colon sections from TNBS-administered guinea-pigs when compared to sections from sham-treated animals (Table 2, Fig. 4f-g). Treatment with $1 \times 10^{5}$ MSCs improved the nerve fibre density in the mucosa $(P<0.001)$ compared to the TNBS-only administered group. However, the density of fibres in both the mucosa and muscle was still lower compared to the sham-treated group $(P<0.001$ for both) (Table 2, Fig. 4c, f-g). In contrary, the morphology of $\beta$ tubulin (III)-IR fibres in mucosal and muscular layers of colon sections from guinea-pigs treated with $1 \times 10^{6}$ and $3 \times 10^{6}$ MSCs were comparable to those in sections from sham-treated animals (Figs. $4 \mathrm{~d}-\mathrm{e}$ ). When quantified, $\beta$-tubulin (III)-IR fibre density in mucosa and muscles in colon sections from $1 \times 10^{6}$ and $3 \times$ $10^{6}$ MSC-treated guinea-pigs was higher compared to both TNBS-only and $1 \times 10^{5}$ MSC-treated guinea-pigs $(P<0.001$ for all, Fig. $4 \mathrm{f}-\mathrm{g})$.

To investigate whether $1 \times 10^{5}, 1 \times 10^{6}$ and $3 \times 10^{6}$ MSC treatments were effective in preventing loss of myenteric neurons, neuronal cell bodies were labelled with the pan-neuronal marker anti-Hu antibody in whole-mount LMMP preparations of the distal colon 

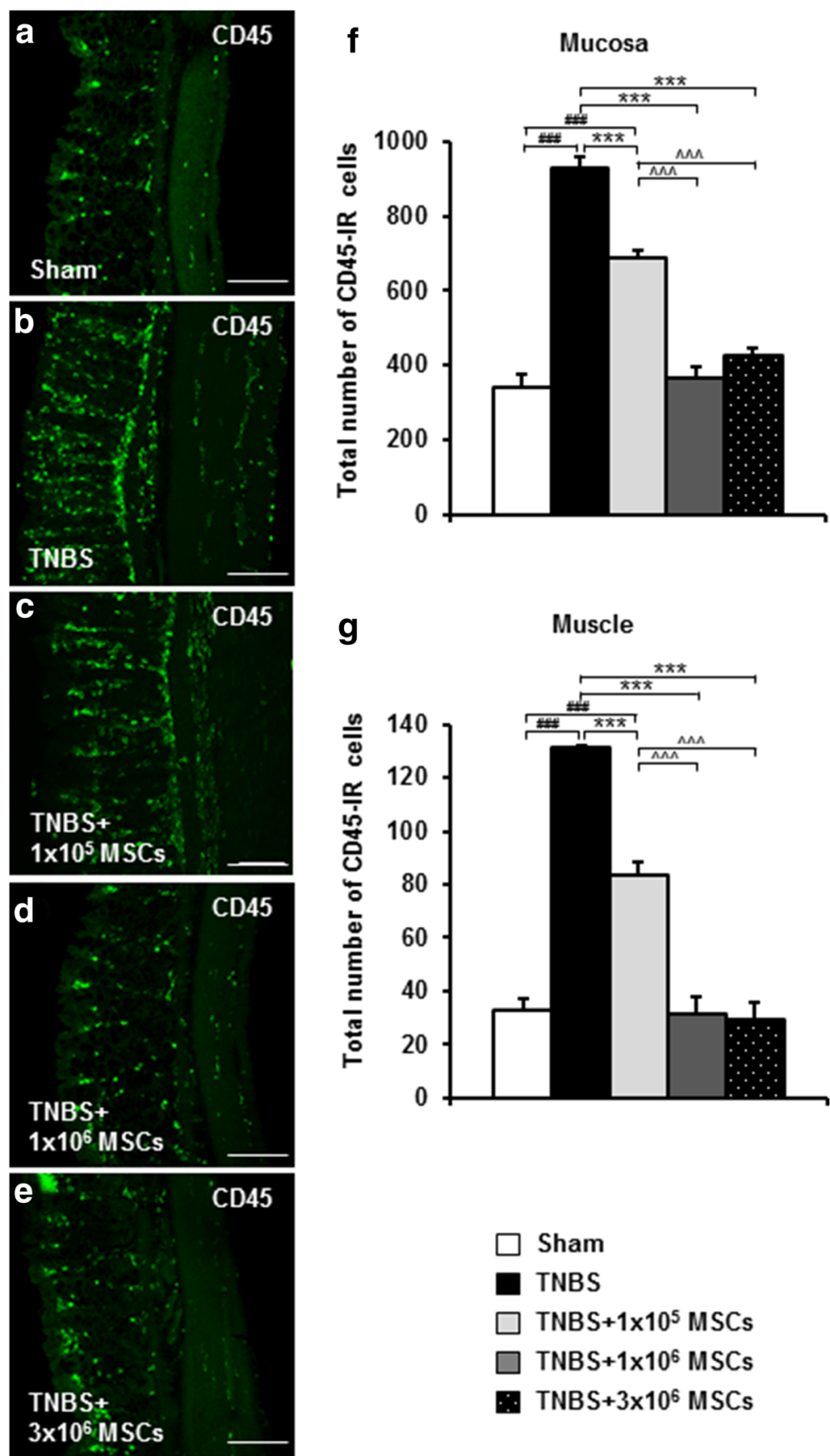

Fig. 3 Leucocyte infiltration in colon cross sections. Sections of the guinea-pig distal colon were labelled with pan-leucocyte marker anti-CD45 to observe the effects of MSC treatments on leucocyte infiltration. CD45-IR leucocytes were visualized within the mucosa and muscular layers of distal colon sections from guinea-pigs collected at 72 hours post induction of colitis (a-e). Scale bars $=100 \mu m$. The total number of CD45-IR cells per $1.5 \mathrm{~mm}^{2}$ area quantified in the mucosa $(\mathbf{f})$ and muscular $(\mathbf{g})$ layers of the colon cross sections. ${ }^{\# \#} P<0.001$ when compared to sham-treated guinea-pigs, ${ }^{* * *} P<0.001$ when compared to TNBS-only administered guinea-pigs, $\wedge \wedge \wedge P<0.001$ when compared to $1 \times 10^{5}$ MSC-treated guinea-pigs. $n=4 /$ group/time point. IR immunoreactive, MSCs mesenchymal stem cells, TNBS 2,4,6-trinitrobenzene sulfonic acid

(Fig. 5). The number of $\mathrm{Hu}-\mathrm{IR}$ neurons was counted per ganglion and per $2 \mathrm{~mm}^{2}$ area. The number of Hu-IR myenteric neurons was decreased in colon preparations from TNBS-only guinea-pigs compared to sham-treated animals (ganglia: $P<0.05$; area: $P<0.01$ ) (Table 2, Fig. 5a-b, f-g). Treatment with $1 \times 10^{5}$ MSCs did not prevent myenteric neuronal loss associated with colitis (Table 2, Fig. 5c, f-g). However, treatments with $1 \times 10^{6}$ and $3 \times 10^{6}$ MSCs attenuated neuronal loss associated with TNBSinduced inflammation (ganglia: $P<0.01$ for both; area: 
Table 2 Dose-dependent effects of MSC treatment on leucocyte infiltration, nerve fibre density and number of myenteric neurons in the inflamed distal colon

\begin{tabular}{|c|c|c|c|c|c|}
\hline & Sham & TNBS & $\mathrm{TNBS}+1 \times 10^{5} \mathrm{MSCs}$ & TNBS $+1 \times 10^{6} \mathrm{MSCS}$ & $\mathrm{TNBS}+3 \times 10^{6} \mathrm{MSCS}$ \\
\hline \multicolumn{6}{|c|}{ Total no. CD45-IR cells } \\
\hline Mucosa & $341 \pm 34$ & $927 \pm 31^{\# \# \#}$ & $686 \pm 23^{* * * \# \# \#}$ & $368 \pm 27^{* * * \wedge \wedge \wedge}$ & $425 \pm 25^{* * * \wedge \wedge \wedge}$ \\
\hline Muscle & $33 \pm 4$ & $131 \pm 1^{\# \# \#}$ & $83 \pm 5^{* * * \# \# \#}$ & $32 \pm 6^{* * * \wedge \wedge \wedge}$ & $29 \pm 6^{* * * \wedge \wedge \wedge}$ \\
\hline \multicolumn{6}{|c|}{$\beta$-tubulin (III)-IR fibre density } \\
\hline Mucosa & $3.31 \pm 0.09$ & $1.68 \pm 0.05^{\# \# \#}$ & $2.54 \pm 0.05^{* * \# \# \#}$ & $3.39 \pm 0.08^{* * * \wedge \wedge \wedge}$ & $3.35 \pm 0.04^{* * * \wedge \wedge \wedge}$ \\
\hline Muscle & $5.54 \pm 0.17$ & $4.03 \pm 0.11^{\# \# \#}$ & $3.93 \pm 0.07^{\# \# \#}$ & $5.67 \pm 0.10^{* * * \wedge \wedge \wedge}$ & $5.50 \pm 0.12^{* * * \wedge \wedge \wedge}$ \\
\hline \multicolumn{6}{|c|}{ Total no. of Hu-IR myenteric neurons } \\
\hline Ganglia & $124 \pm 2$ & $108 \pm 5^{\#}$ & $104 \pm 2^{\# \#}$ & $128 \pm 3^{* * \wedge \wedge}$ & $127 \pm 4^{* * \wedge \wedge}$ \\
\hline Area & $1498 \pm 13$ & $1330 \pm 41^{\# \#}$ & $1312 \pm 20^{\# \# \#}$ & $1510 \pm 19^{* * * \wedge \wedge}$ & $1513 \pm 12^{* * * \wedge \wedge \wedge}$ \\
\hline \multicolumn{6}{|c|}{ Total no. of nNOS-IR myenteric neurons } \\
\hline Ganglia & $22 \pm 1$ & $27 \pm 1^{\# \#}$ & $27 \pm 1^{\# \# \#}$ & $20 \pm 1 * * \wedge \wedge$ & $22 \pm 1^{* * \wedge \wedge \wedge}$ \\
\hline Area & $262 \pm 12$ & $318 \pm 7^{\# \# \#}$ & $317 \pm 5^{\# \# \#}$ & $277 \pm 6^{* * \wedge \wedge}$ & $246 \pm 3^{* * * \wedge \wedge \wedge}$ \\
\hline \multicolumn{6}{|c|}{ Proportion of nNOS-IR myenteric neurons } \\
\hline Ganglia & $17 \pm 1$ & $26 \pm 2^{\# \# \#}$ & $27 \pm 1^{\# \# \#}$ & $16 \pm 1^{* * * \wedge \wedge \wedge}$ & $18 \pm 1^{* * * \wedge \wedge \wedge}$ \\
\hline Area & $17 \pm 1$ & $24 \pm 1^{\# \# \#}$ & $24 \pm 1^{\# \# \#}$ & $18 \pm 1^{* * * \wedge \wedge \wedge}$ & $16 \pm 1^{* * * \wedge \wedge \wedge}$ \\
\hline \multicolumn{6}{|c|}{ Total no. of ChAT-IR myenteric neurons } \\
\hline Ganglia & $67 \pm 1$ & $52 \pm 2^{\# \#}$ & $57 \pm 2^{\# \#}$ & $64 \pm 2^{* * \wedge}$ & $65 \pm 3^{* * \wedge}$ \\
\hline Area & $749 \pm 29$ & $545 \pm 24^{\# \# \#}$ & $585 \pm 23^{\# \#}$ & $708 \pm 29 * \wedge$ & $743 \pm 14^{* * * \wedge \wedge}$ \\
\hline \multicolumn{6}{|c|}{ Proportion of ChAT-IR myenteric neurons } \\
\hline Ganglia & $54 \pm 1$ & $49 \pm 1$ & $55 \pm 1$ & $50 \pm 1$ & $52 \pm 4$ \\
\hline Area & $50 \pm 2$ & $41 \pm 1^{\# \#}$ & $45 \pm 2$ & $47 \pm 2^{*}$ & $49 \pm 1^{*}$ \\
\hline
\end{tabular}

MSC mesenchymal stem cell, TNBS 2,4,6-trinitrobenzene sulfonic acid, IR immunoreactive, nNOS neuronal nitric oxide synthase, ChAT Choline acetyltransferase \#P $<0.05,{ }^{\# \#} P<0.01, \# \# P<0.001$ when compared to sham-treated guinea-pigs

${ }^{*} P<0.05,{ }^{*} P<0.01,{ }^{* * *} P<0.001$ when compared to TNBS-only administered guinea-pigs

$\wedge P<0.05, \wedge \wedge P<0.01, \wedge \wedge \wedge P<0.001$ when compared to $1 \times 10^{5}$ MSC-treated guinea-pigs

$P<0.001$ for both) compared to the TNBS group (Table 2, Fig. 5d-e, f-g).

\section{Dose-dependent effects of MSC treatments on inhibitory and excitatory myenteric neurons}

Changes in inhibitory and excitatory myenteric muscle motor and interneurons underlie inflammation-induced colonic dysmotility, therefore we investigated the effects of MSC-based therapies on these two major subpopulations of neurons. Inhibitory neurons were labelled with anti-nNOS antibody in whole-mount LMMP preparations of the distal colon (Fig. 6). The number of nNOSIR neurons per ganglion and per area was increased in the myenteric plexus from the TNBS-only group compared with sham-treated animals (ganglia: $P<0.01$; area: $P<0.001)$. The proportion of nNOS-IR neurons to the total number of $\mathrm{Hu}$-IR neurons was increased in TNBSonly guinea-pigs compared with sham-treated $(P<0.001$ for all) (Table 2, Fig. 6a-b, f-i). The number and proportion of nNOS-IR neurons were comparable between TNBS-only administered guinea-pigs and $1 \times 10^{5}$ MSCtreated animals (Table 2, Fig. 6c). Thus, nNOS-IR neurons were elevated in preparations from $1 \times 10^{5}$ MSC-treated animals compared to sham-treated $(P<$ 0.001 for both ganglia and area), $1 \times 10^{6}$ MSC-treated $\left(P<0.01\right.$ for both ganglia and area) and $3 \times 10^{6}$ MSCtreated $(P<0.001$ for both ganglia and area) guinea-pigs (Table 2, Fig. 6f-i). Correspondingly, the proportion of nNOS-IR neurons was also increased $(P<0.001$ for all). Both $1 \times 10^{6}$ and $3 \times 10^{6}$ MSC treatments prevented the increase in the total number $\left(1 \times 10^{6}\right.$ - ganglia: $P<0.001$; area: $P<0.01 ; 3 \times 10^{6}$ - ganglia: $P<0.01$; area: $\left.P<0.001\right)$ and proportion $(P<0.001$ for all $)$ of nNOS-IR neurons compared to the TNBS-only group (Table 2, Fig. 6d-e, f-i).

Excitatory muscle motor and interneurons were identified using ChAT immunoreactivity in whole-mount preparations of the distal colon (Fig. 7). Quantification of ChAT-IR neurons revealed a decrease in the TNBSonly group compared to sham-treated guinea-pigs (ganglia: $P<0.01$; area: $P<0.001$ ) (Table 2, Fig. $7 \mathrm{a}-\mathrm{b}, \mathrm{f}, \mathrm{h}$ ). The number of ChAT-IR neurons in preparations from $1 \times 10^{5}$ MSC-treated guinea- pigs was comparable to the TNBS-only group, indicating that this dose was not effective in preventing the TNBS-induced decrease in 

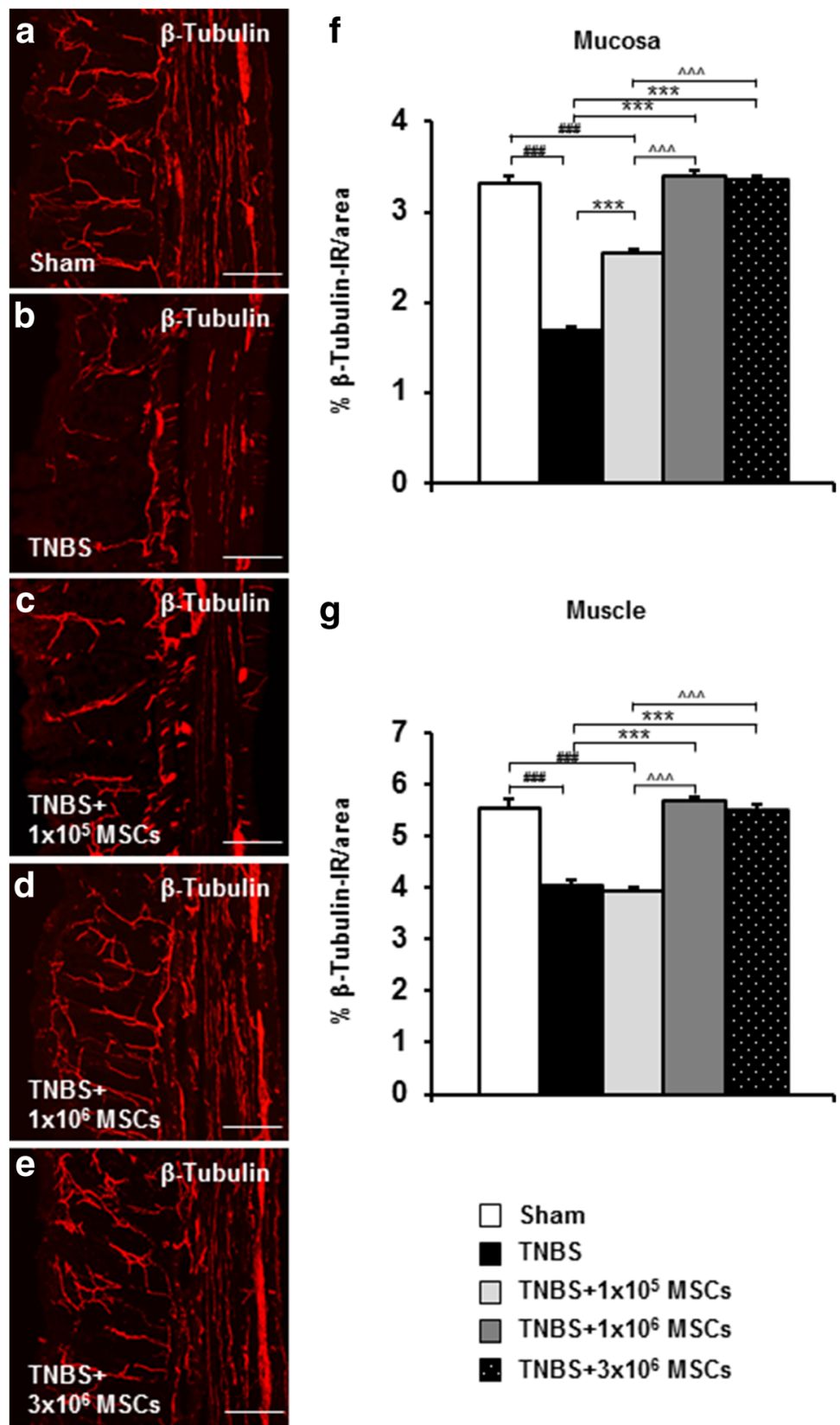

Fig. 4 Nerve fibres in cross sections of the distal colon. Distribution of fibres labelled by neuron-specific anti- $\beta$-tubulin (III) antibody in colon sections from sham-treated, TNBS-only, $1 \times 10^{5}$ MSC-treated, $1 \times 10^{6}$ MSC-treated and $3 \times 10^{6}$ MSC-treated guinea-pigs at 72 hours post induction of colitis (a-e). Scale bars $=100 \mu \mathrm{m}$. $\beta$-tubulin (III)-IR fibres were quantified in the mucosa (f) and muscular (g) layers of the colon. ${ }^{\# \# \#<0.001}$ when compared to sham-treated guinea-pigs, ${ }^{* * *} P<0.001$ when compared to TNBS-only administered guinea-pigs, $\wedge \wedge \wedge P<0.001$ when compared to $1 \times 10^{5}$ MSC-treated guinea-pigs. $n=4 /$ group/time point. IR immunoreactive, MSCs mesenchymal stem cells, TNBS 2,4,6-trinitrobenzene sulfonic acid

ChAT-IR neurons (Table 2, Fig. 7c, f, h). ChAT-IR neurons were reduced in $1 \times 10^{5}$ MSC-treated animals compared to sham-treated $(P<0.01$ for both ganglia and area), $1 \times 10^{6}$ MSC-treated $(P<0.05$ for both ganglia and area) and $3 \times 10^{6}$ MSC-treated (ganglia: $P<0.05$; area: $P<0.01)$ guinea-pigs. Treatment with $1 \times 10^{6} \mathrm{MSCs}$ $\left(P<0.01\right.$ for both ganglia and area) and $3 \times 10^{6}$ MSCs (ganglia: $P<0.01$; area: $P<0.001$ ) prevented the TNBSinduced loss of ChAT-IR neurons with numbers comparable to the sham-treated group (Table 2, Fig. 7d-e, f, h). When quantified per ganglia, there were no differences between any groups in the proportion of ChAT-IR neurons to total number of neurons (Fig. 7g). However, when quantified per area (Fig. 7i), the proportion of ChAT-IR neurons 

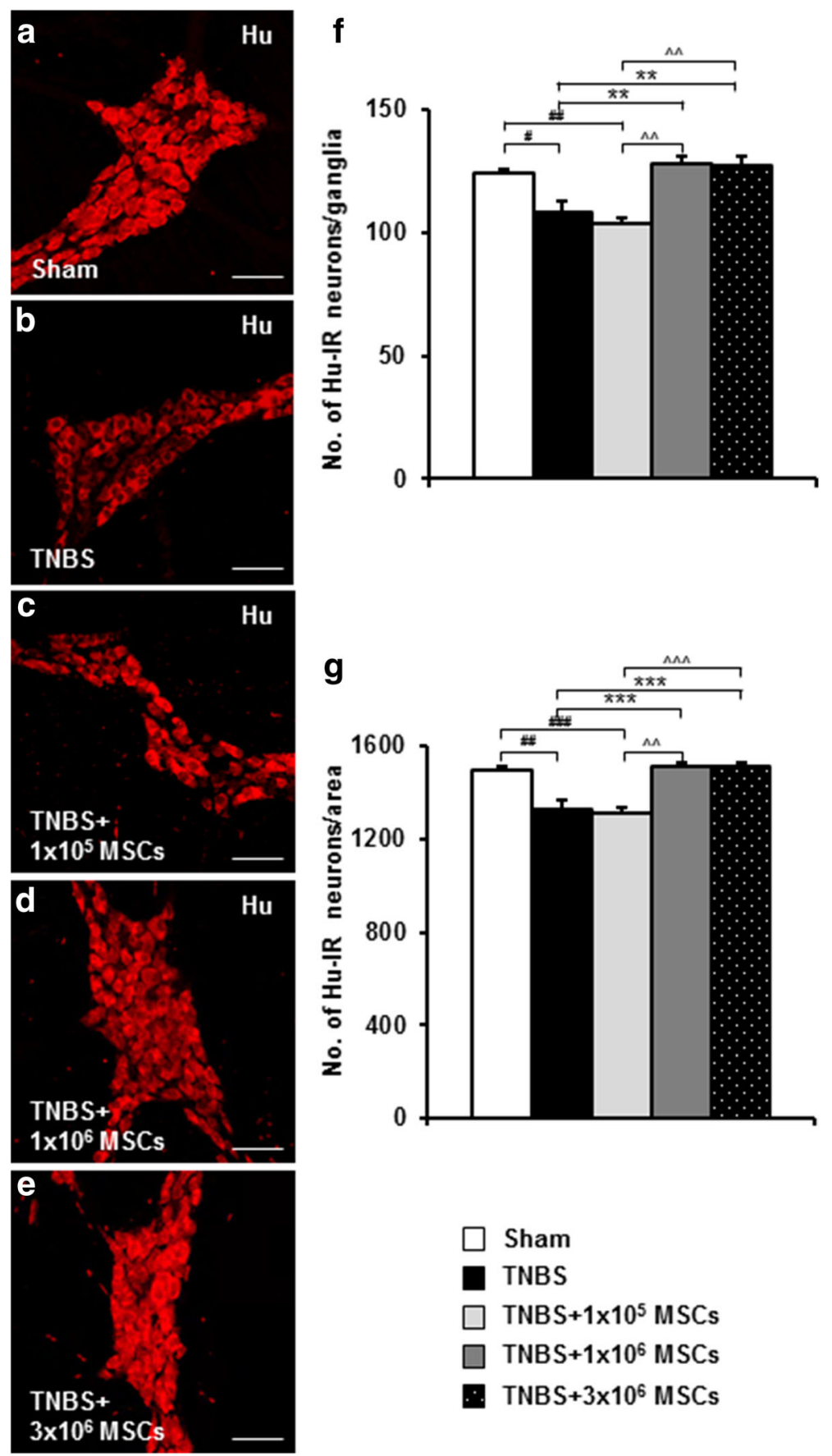

Fig. 5 Effects of MSC treatments on the total number of myenteric neurons. Myenteric neurons were identified by anti-Hu antibody in whole-mount LMMP preparations of the distal colon from sham-treated, TNBS-only, $1 \times 10^{5}$ MSC-treated, $1 \times 10^{6}$ MSC-treated and $3 \times 10^{6}$ MSC-treated guinea-pigs 72 hours post induction of colitis (a-e). Scale bars $=100 \mu \mathrm{m}$. The total number of Hu-IR neurons were counted per ganglion (average of ten ganglia) (f) and per $2 \mathrm{~mm}^{2}$ area $(\mathbf{g})$ of the colon. ${ }^{\#} P<0.05,{ }^{\# \#} P<0.01,{ }^{\# \#} P<0.001$ when compared to sham-treated guinea-pigs, ${ }^{* *} P<0.01,{ }^{* * *} P<0.001$ when compared to TNBS-only administered guinea-pigs, $\wedge \wedge P<0.01, \wedge \wedge \wedge P<0.001$ when compared to $1 \times 10^{5}$ MSC-treated guinea-pigs. $n=4 /$ group/time point. IR immunoreactive, LMMP longitudinal muscle-myenteric plexus, MSCs mesenchymal stem cells, TNBS 2,4,6-trinitrobenzene sulfonic acid

to $\mathrm{Hu}$-IR neurons was reduced in TNBS-only administered animals when compared to sham-treated $(P<0.01), 1 \times 10^{6}$ MSC-treated $(P<0.05)$ and $3 \times 10^{6}$ MSC-treated $(P<0.05)$ guinea-pigs.

\section{Discussion}

In this study, we compared different doses of human BM-MSCs for their neuroprotective efficacy in a guineapig model of TNBS-induced colitis. Both $1 \times 10^{6}$ and 

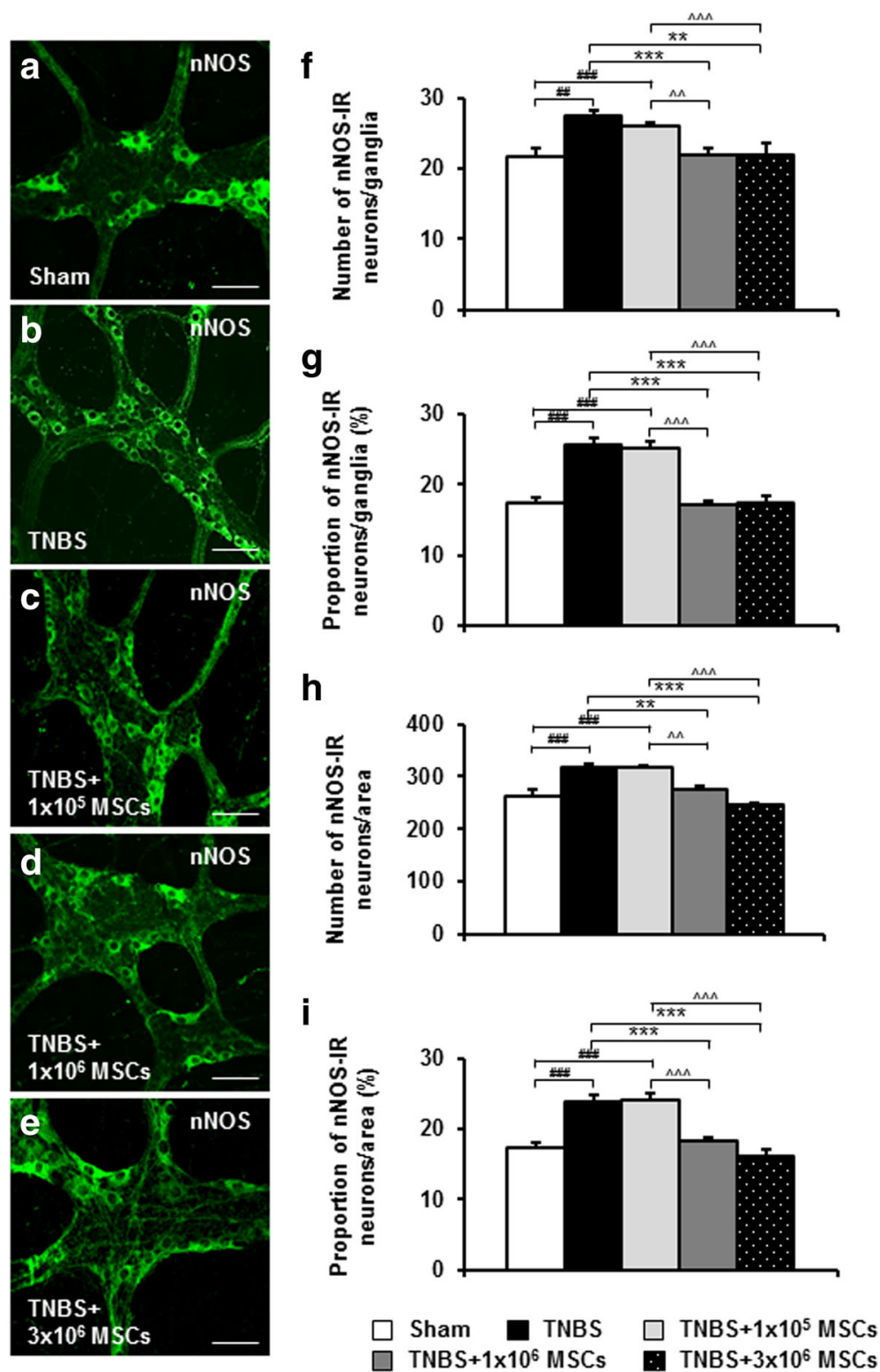

Fig. 6 Effects of MSC treatments on nNOS-IR myenteric neurons. Inhibitory myenteric neurons were identified by anti-nNOS antibody in whole-mount LMMP preparations of the distal colon from sham-treated, TNBS-only, $1 \times 10^{5}$ MSC-treated, $1 \times 10^{6}$ MSC-treated and $3 \times 10^{6}$ MSC-treated guinea-pigs at 72 hours post induction of colitis (a-e). Scale bars $=100 \mu \mathrm{m}$. The total number of nNOS-IR neurons was counted per ganglion (average of ten ganglia) (f) and per $2 \mathrm{~mm}^{2}$ area (h) of the colon. The proportion of nNOS-IR neurons to Hu-IR neurons per ganglia ( $\mathbf{g}$ ) and per $2 \mathrm{~mm}^{2}$ area (i). ${ }^{\# \#} P<0.01$, ${ }^{\# \#} P<0.001$ when compared to sham-treated guinea-pigs, ${ }^{* *} P<0.01,{ }^{* * *} P<0.001$ when compared to TNBS-only administered guinea-pigs, $\wedge \wedge P<0.01, \wedge \wedge \wedge P<0.001$ when compared to $1 \times 10^{5}$ MSC-treated guinea-pigs. $n=4$ /group/time point. LMMP longitudinal muscle-myenteric plexus, nNOS neuronal nitric oxide synthase, IR immunoreactive, MSCs mesenchymal stem cells, TNBS 2,4,6-trinitrobenzene sulfonic acid

$3 \times 10^{6}$ MSC treatments demonstrated therapeutic efficacy in the accelerated repair of colonic architecture, reduced leucocyte infiltration transmurally through the colon wall, regeneration of nerve fibres, and were equally neuroprotective in the amelioration of myenteric neuronal loss and changes to the neurochemical coding of their subpopulations. When administered at a dose of
$1 \times 10^{5}$, BM-MSCs offered some therapeutic benefit in healing of the colonic architecture, protection of nerve fibres and the offset of CD45-IR cells in the mucosa, however, were less effective in the attenuation of neuropathy at the level of the myenteric plexus. Thus, a dose of $1 \times 10^{6}$ MSCs is necessary to ameliorate the effects of TNBS-induced inflammation at the level of the 

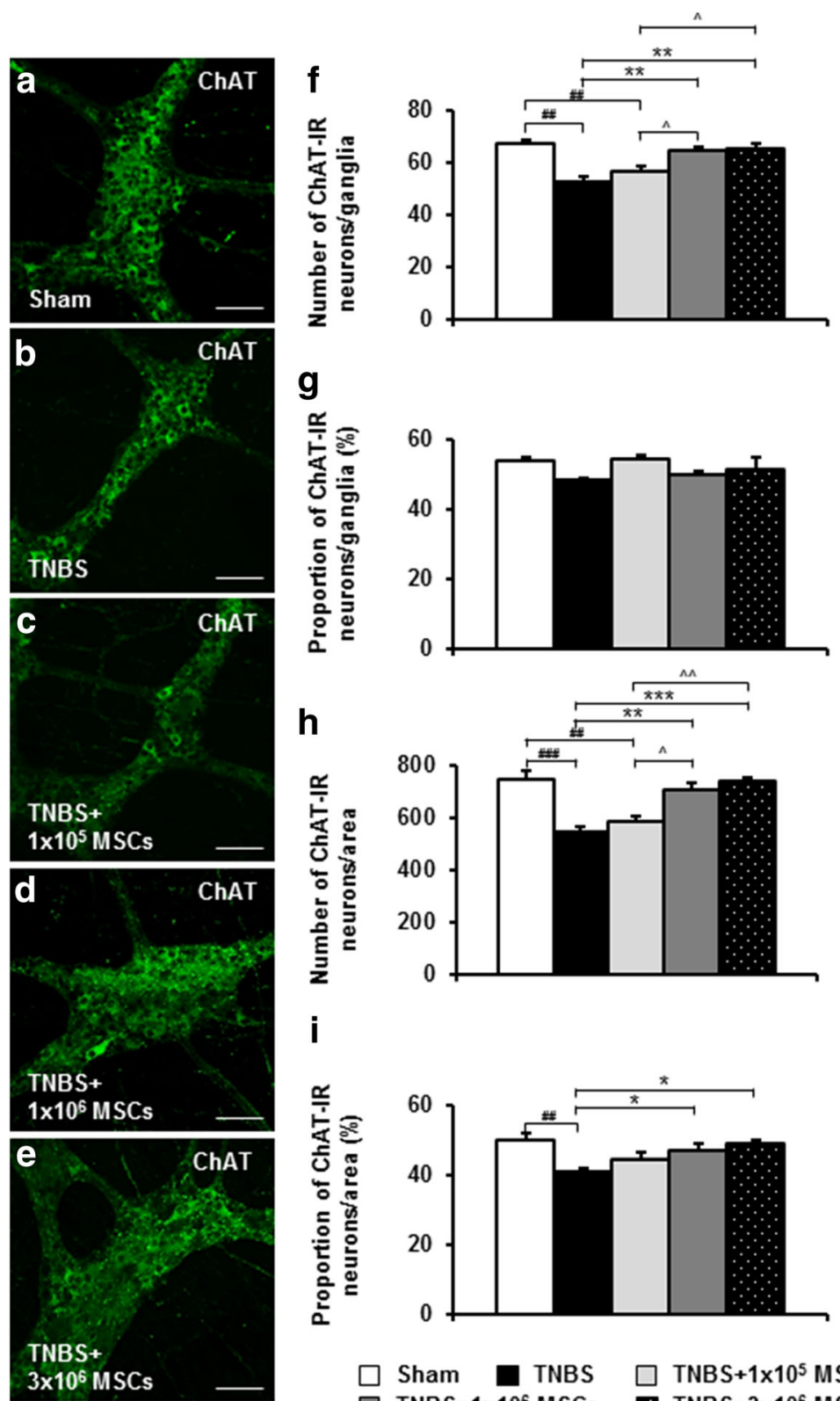

i

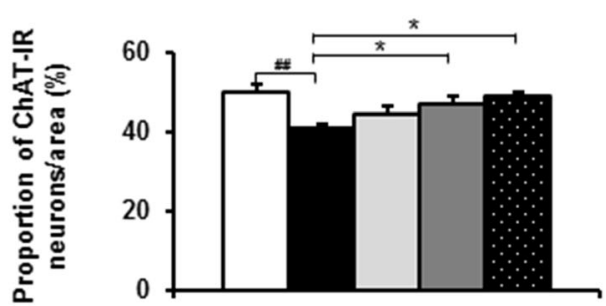

\section{$\square$ Sham $\square$ TNBS $\square$ TNBS $+1 \times 10^{5}$ MSCs \\ TNBS $+1 \times 10^{6} \mathrm{MSCs}$ TNBS $+3 \times 10^{6} \mathrm{MSCs}$}

Fig. 7 Effects of MSC treatments on ChAT-IR myenteric neurons. Excitatory myenteric neurons were identified by anti-ChAT antibody in whole-mount preparations of the distal colon from sham-treated, TNBS-only, $1 \times 10^{5}$ MSC-treated, $1 \times 10^{6}$ MSC-treated and $3 \times 10^{6}$ MSC-treated guinea-pigs (a-e). Scale bars $=100 \mu \mathrm{m}$. The total number of ChAT-IR neurons were counted per ganglion (average of ten ganglia) (f) and per $2 \mathrm{~mm}^{2}$ area (h) of the colon. The proportion of ChAT-IR neurons to Hu-IR neurons per ganglia $(\mathbf{g})$ and per area (i). ${ }^{\# \#} P<0.01$, ${ }^{\# \#} P<0.001$ when compared to sham-treated guineapigs, ${ }^{* *} P<0.01,{ }^{* *} P<0.001$ when compared to TNBS-only administered guinea-pigs, $\wedge P<0.05, \wedge \wedge P<0.01$ when compared to $1 \times 10^{5}$ MSC-treated guinea-pigs. $n=4$ /group/time point. ChAT choline acetyltransferase, IR immunoreactive, MSCs mesenchymal stem cells, TNBS 2,4,6-trinitrobenzene sulfonic acid

myenteric plexus; further increases in dose provide consistent efficacy without promotion of benefit.

In IBD patients with fistulae and luminal inflammation it has been demonstrated that therapy with both BM and adipose MSCs is safe, feasible and efficacious [60-64]. However, there is inconsistency regarding the most effective dose; some studies report reduced disease activity and fistula closure with doses ranging from $3 \times 10^{6}-60 \times 10^{6}$ MSCs $[60,61,65,66]$. Additionally, some studies have reported positive outcomes with dose regimes based relative to fistula size (dose range $1 \times 10^{6}-4 \times$ $10^{7}$ cells/cm length of fistula (average number of injected cells: $\left.\left.20 \times 10^{6}-15.8 \times 10^{7}\right)\right)[63,67,68]$ or patient bodyweight $\left(1 \times 10^{6}-2.7 \times 10^{6}\right.$ cells $\left./ \mathrm{kg}\right)[62,64]$. 
In experimental models of colitis, BM-MSCs derived from rats $[52-54,69-71]$, mice $[55,72-74]$, guineapigs [56] and humans [25, 35, 56, 57, 75, 76] have been investigated for therapeutic efficacy. In addition, some studies have assessed adipose MSCs derived from these species [51, 56, 70, 77-80], as well as human umbilical cord, umbilical cord blood and gingiva [75, 81-83]. Overall, intravenous, intraperitoneal and local administration of MSCs from various sources and species have been reported to ameliorate experimental colitis however, similarly to clinical trials, there is no consistency regarding the most efficacious dose. Studies report therapeutic efficacy in ameliorating colitis following MSC application with doses of $2 \times 10^{3}$ [69], $2 \times 10^{4}$ [54], $5 \times 10^{5}$ [71], $0.5 \times 10^{6}$ [76], $1 \times 10^{6}[25,35,51,55-57,72-74,76$, $78,79,81,83], 2 \times 10^{6}[70,75,80,82], 5 \times 10^{6}[51,53]$, $1 \times 10^{7}$ [52, 77] MSCs.

In this study, we employed MSCs derived from human BM. Human MSCs are the most characterized, clinically applied as a potential regenerative cell therapy [84] and defined based upon three minimal criteria (i) plastic adherence, (ii) trilineage differentiation, (iii) surface expression of CD73, CD90, CD105 and absence of expression of CD45, CD34, CD14 or CD11b, CD79 $\alpha$ or CD19, and human leucocyte antigen (HLA)-DR [58]. MSCs used in this study were validated according to these guidelines issued by the International Society for Cellular Therapy. On the other hand, MSCs from animal origin have been defined as cells that fulfil the first two criteria [45]. Comparison of animal and human-derived MSCs has revealed a high degree of concordance [85-87]. However, differences have been reported in genomic stability [88, 89], differentiation potential [90], surface antigen expression and immunoregulatory capabilities [91] making it difficult to directly extrapolate the results obtained on animal MSCs to human MSCs. MSCs were originally derived from the BM, are the most frequently investigated cell type [92] and are often designated as the gold standard in the treatment of various inflammatory conditions [93-96]. Furthermore, human BM-MSCs are the most therapeutic in the treatment of enteric neuropathy and plexitis associated with TNBS-induced colitis [57].

Of particular relevance to the therapeutic application of MSCs is their fate post-implantation. Ambiguity seen in the efficacy of MSCs, in both animal studies and clinical trials, with therapies being ineffective or only temporarily effective could be due to suboptimal application of MSCs. Previous studies have indicated MSC efficacy may be affected by the timing of delivery [28] and administration during the earlier phases of inflammation is favourable for therapeutic results [97-99]. Therefore, in consistency with our previous studies, BM-MSCs were administered 3 hours after TNBS; the time point when substantial mucosal damage occurs [59].
The migratory and homing capacity of MSCs is facilitated by their expression of a wide array of chemokine receptors and adhesion molecules that respond to chemoattractant signals released from host cells at the site of injury [97]. MHC class I molecules are expressed on the surface of viable human MSCs promoting immune rejection and assisting in engraftment into damaged tissue via the absence of co-stimulatory ligands/ receptors and release of immunosuppressive factors [45, $100,101]$. MSC migration to the area of inflammation and subsequent engraftment into the damaged tissue is an inaugural part of the tissue repair/regeneration process and indispensable for therapeutic efficacy. In this study, we labelled sections of the guinea-pig colon with anti-HLA-A,B,C antibody to evaluate the successful migration and engraftment of MSCs within the inflamed intestinal wall. MSCs engrafted into the mucosa at the initial site of TNBS-induced inflammation in all MSCtreated groups. However, in sections from guinea-pigs administered $1 \times 10^{6}$ or $3 \times 10^{6}$ MSCs, HLA-A,B,C-positive cells were observed at the level of the myenteric plexus in addition to the mucosal layer. The successful migration and engraftment of enema-applied MSCs into the inflamed colonic wall observed in our study is consistent with previous reports demonstrating implantation of locally administered MSCs into target tissues, especially in inflammatory conditions $[52,102]$. Subsequently, the outcomes of the treatment were more pronounced in animals treated with $1 \times 10^{6}$ and $3 \times$ $10^{6}$ MSCs compared to those treated with $1 \times 10^{5}$ MSCs.

Reduced disease activity, endoscopic and histopathologic severity of colitis, and infiltration of neutrophils into the colon are commonly evaluated to determine the effectiveness of MSC treatments in both clinical trials and experimental models of IBD. Within these parameters examining the therapeutic efficacy of various MSC doses at the level of the mucosa only, we could conclude that BM-MSCs ameliorate experimental colitis at a dose as low as $1 \times 10^{5}$ MSCs. However, previous studies have reported marked structural and functional changes to the ENS in IBD accompanied by infiltration of inflammatory cells to the submucosa and myenteric plexus [103-105]. Alterations to the ENS persist long after resolution of acute intestinal inflammation reflected through changes in gut function, colonic dysmotility, hypersensitivity and dysfunction [104, 106], and myenteric plexitis has been shown to be predictive of IBD recurrence $[103,105]$. Therefore, we further investigated the therapeutic efficacy of varying doses of BM-MSCs at the level of the myenteric plexus.

In this study, MSCs were effective in reducing leucocyte infiltration to the myenteric plexus when administered at doses of $1 \times 10^{6}$ and $3 \times 10^{6}$, but not at a dose of 
$1 \times 10^{5}$. It may be proposed that while some immunomodulatory effect is occurring following application of $1 \times 10^{5}$ MSCs, it is not strong enough to combat all inflammation since leucocyte numbers were reduced at the mucosal level in this group, but not at the myenteric level. While the immunomodulatory mechanisms of MSCs have not been completely elaborated, it is known that in order for MSCs to wield their immunosuppressive capacities, they must be induced by inflammatory cytokines within a pro-inflammatory microenvironment [107]. The increased numbers of leucocytes in the colonic wall following induction of TNBS colitis provided sufficient pro-inflammatory stimuli for activation of MSCs. Hence, the weaker influence demonstrated by the lower dose of MSCs suggests that the anti-inflammatory effect was hindered by a smaller quantity of MSCs rather than their immunomodulatory capacity. This is reflected by localization of MSCs within the inflamed colon where HLA-A,B,C-positive cells were evident in the mucosa only in sections from $1 \times 10^{5}$ MSC-treated animals.

It is generally considered that the anti-inflammatory properties of MSCs function via direct interaction with target cells and/or production of diverse soluble factors [34, 108]. Many of the MSC-associated biological effects are mediated by paracrine mechanisms engaging the release of cytokines, chemokines and growth factors [34, $109,110]$ and may be exerted by the induction and stimulation of endogenous host progenitor cells to improve the regenerative process $[72,111]$. In animal models of colitis, MSC application efficiently reduces T helper 1 and $\mathrm{T}$ helper 17 responses and downregulates pro-inflammatory cytokines (such as tumour necrosis factor alpha (TNF- $\alpha$ ), interleukin (IL)-1 $\beta$, IL-6, IL-17, inducible nitric oxide synthase (iNOS), cyclooxygenase-2 (COX-2) and interferon gamma (IFN- $\gamma$ ) while enhancing the numbers of regulatory $\mathrm{T}$ cells and upregulating antiinflammatory cytokines (such as IL-10) [112-115]. The proportion of mucosal and peripheral regulatory $\mathrm{T}$ cells was also increased after MSC treatment of CD fistulae [63]. These findings suggest that the paracrine actions of MSCs have an anti-inflammatory affect in IBD associated with inhibition of nuclear factor kappa B (NF-кB) signalling pathways. Furthermore, paracrine actions of MSCs have be shown to diminish free radicals and impede oxidative stress, prevent apoptosis via the extrinsic death receptor signal pathway and the intrinsic mitochondrial signal pathway and stimulate endogenous mechanisms of intestinal epithelial repair [111, 112].

It remains unclear whether changes to the ENS are the cause or the consequence of inflammation; however, in this study TNBS-induced plexitis was associated with damage to nerve fibres and loss of myenteric neurons, as well as changes in their subpopulations. Similar to the limited anti-inflammatory effect discussed above, sections from animals treated with $1 \times 10^{5}$ MSCs revealed some nerve fibre regrowth, but not to the level of sham-treated animals. In contrast, significant regeneration and regrowth of nerve fibres in the colon were associated with $1 \times 10^{6}$ and $3 \times 10^{6}$ MSC treatments in this study. MSCs improve axonal and nerve regeneration through the production of local neurotrophic factors for induction of axonal growth, including brain-derived neurotrophic factor, nerve growth factor and insulin-like growth factor-1 [116, 117]. Hence, differences in the level and areas of MSC engraftment demonstrated in sections from $1 \times 10^{5}$ MSC-treated animals compared to $1 \times 10^{6}$ and $3 \times 10^{6}$ MSC-treated guinea-pigs maybe associated with a reduction in the expression of neurotrophic factors. However, this needs to be further investigated.

Our study demonstrated a persistent loss of myenteric neurons to be associated with TNBS-induced inflammation in the distal colon of guinea-pigs 72 hours after induction of colitis. Consistent with our findings, the quantity of myenteric neurons was found to be reduced in the guinea-pig intestine subsequent to intra-rectal administration of TNBS in previous studies $[16,21,25,35$, $56,57]$. In this study, neuronal loss was not prevented following treatment with $1 \times 10^{5} \mathrm{MSCs}$ and the number of myenteric neurons was comparable to the TNBS-only administered group. On the other hand, doses of $1 \times 10^{6}$ and $3 \times 10^{6}$ MSCs prevented the neuronal loss associated with TNBS-induced inflammation. Similarly, MSCs have been shown to prevent neuronal apoptosis [118], increase the survival of motor neurons in amyotrophic lateral sclerosis (ALS) $[119,120]$ and reduce the loss of dopaminergic neurons in Parkinson's disease [121]. Furthermore, in a dose-dependent study, $1 \times 10^{6}$ BM-MSCs was optimal to reduce the extent of neural loss in mice with ALS [50].

Enteric neuropathy in intestinal inflammation may be influenced by excessive nitric oxide [122], while inflammation-associated loss of ChAT-IR neurons has been associated with decreases in the number of myenteric neurons $[15,19,123,124]$. An increase in the total number of nNOS neurons, as well as a decrease in the number of ChAT neurons was revealed 72 hours after the induction of colitis. These results are consistent with previous studies using tissues from IBD patients and experimental animals describing alterations in the neurochemical coding of enteric neurons $[16,23,24$, $125,126]$. In this study, treatment with $1 \times 10^{5}$ MSCs was not effective in attenuating changes in the neurochemical coding of excitatory and inhibitory myenteric neurons. However, the increase in nNOS-IR neurons, as well as the loss of ChAT-IR neurons was attenuated by $1 \times 10^{6}$ and $3 \times 10^{6}$ MSCs. The neurons of the myenteric plexus are primarily responsible for coordinating muscular contraction [14] and prevention of changes to 
neurochemical coding by MSC treatments has been associated with alleviating TNBS-induced changes to colonic motility [25]. Thus, attenuating changes in the subpopulations of myenteric neurons may alleviate dysmotility associated with intestinal inflammation.

In consistency with our findings, MSCs have been reported to reduce neurological defects and promote functional recovery in experimental models of neurodegenerative diseases [127-131]. While the exact mechanisms of MSC neuroprotection remain unknown, MSCs can act via paracrine mechanisms secreting neuroregulatory molecules, cytokines, growth factors and chemokines, which provide neuroprotective and neurorestorative effects [132]. These effects include enhancing neuronal viability, promoting regeneration of nerve fibres and inducing the proliferation and differentiation of endogenous neural progenitor cells [133-135]. Furthermore, studies investigating the MSC secretome suggest that numerous bioactive factors secreted by MSCs mediate neuroprotection via tropic support, immunomodulation and anti-apoptosis [134, 135]. The exact MSC-mediated signalling network responsible for neuroprotection of enteric neurons requires further investigation.

In this study, we have observed distinct differences between MSC doses in preventing enteric neuropathy associated with intestinal inflammation. From these results, we can determine that a $1 \times 10^{5}$ dose of BM-MSCs is not adequate, whereas doses of $1 \times 10^{6}$ and $3 \times 10^{6}$ demonstrate anti-inflammatory and neuroprotective qualities in TNBS-induced colitis. Although the $3 \times 10^{6}$ dose MSCs contained triple the quantity of cells than the $1 \times 10^{6}$ dose, no differences were evident between the magnitude of cells homing to and engrafting at the site of tissue injury. This suggests a dose saturation indicating that although there is a greater number of cells being transplanted in vivo, only the required number migrates and engrafts into the inflamed areas of TNBS-induced colitis. This is consistent with a previous MSC study which revealed the engraftment of osteoprogenitor cells to be saturated and concluded that higher doses of cells would be an ineffective strategy to improve engraftment [136]. Furthermore, high-dose inhibition of cytokines has also been observed with high concentrations of MSCs [137-139].

\section{Conclusions}

In this study we have essentially determined an optimal dose of MSCs for enteric neuroprotection in TNBSinduced colitis. We have demonstrated that the neuroprotective and anti-inflammatory effect of BM-MSCs is dose-dependent in TNBS-induced colitis; BM-MSCs have the ability to prevent inflammatory insults to the ENS when administered at a dose of $1 \times 10^{6}$ cells 3 hours after induction of colitis, with no further benefit gained from a higher dose. The findings of this study are important for further investigations into the mechanisms of MSC-based enteric neuroprotection, as well as immunomodulation within the inflamed colon, further enabling MSC therapy to continue to advance forward in future studies.

\begin{abstract}
Abbreviations
ALS: Amyotrophic lateral sclerosis; BM: Bone marrow; ChAT: Choline acetyltransferase; DMSO: Dimethyl sulfoxide; FBS: Fetal bovine serum; ENS: Enteric nervous system; H\&E: haematoxylin and eosin; HLA: Human leucocyte antigen; IBD: Inflammatory bowel disease; IL: Interleukin; IR: Immunoreactive; LMMP: Longitudinal muscle-myenteric plexus; MHC: Major histocompatibility complex; MSC: Mesenchymal stem cell; nNOS: Neuronal nitric oxide synthase; OCT: Optimal cutting temperature; PBS: Phosphate-buffered saline; TNBS: 2,4,6-Trinitrobenzene sulfonic acid
\end{abstract}

\section{Acknowledgements}

The authors thank Dr Natalie Payne and Professor Claude Bernard (Monash Immunology and Stem Cell Laboratories (MISCL), Monash University, Melbourne, VIC, Australia) for provision of mesenchymal stem cells.

\section{Funding}

This study was supported by a Victoria University Research and Development Grant Scheme: Near Miss Grant and Central Research Grant Scheme.

\section{Availability of data and materials}

The data that support the findings of this study are available from the corresponding author upon reasonable request.

\section{Authors' contributions \\ AMR wrote the manuscript and performed animal work, immunohistochemical studies, histological studies and statistical analysis. AAR, SM and RS contributed to animal work and immunohistochemical studies. SS helped to supervise the study and obtain funding. KN designed the project, contributed to writing of the manuscript, helped to supervise the study and obtain funding. All authors read and approved the final manuscript.}

Competing interests

The authors declare that they do not have any competing interests.

Consent for publication

Not applicable.

Ethics approval

Animals were obtained from South Australian Health and Medical Research Institute (SAHMRI, Adelaide, SA, Australia). All animal handling and procedures complied with the guidelines of the National Health and Medical Research Council (NHMRC) Australian Code of Practice for the Care and Use of Animals for Scientific Purposes under approval of the Victoria University Animal Experimentation Ethics Committee.

\section{Publisher's Note}

Springer Nature remains neutral with regard to jurisdictional claims in published maps and institutional affiliations.

Received: 2 February 2017 Revised: 14 March 2017

Accepted: 17 March 2017 Published online: 18 April 2017

\section{References}

1. Abraham C, Cho JH. Inflammatory bowel disease. N Engl J Med. 2009;361:2066-78

2. Baumgart DC, Sandborn WJ. Crohn's disease. Lancet. 2012;380:1590-605.

3. Ordás I, Eckmann L, Talamini M, Baumgart DC, Sandborn WJ. Ulcerative colitis. Lancet. 2012;380:1606-19.

4. Fakhoury M, Negrulj R, Mooranian A, Al-Salami H. Inflammatory bowel disease: clinical aspects and treatments. J Inflamm Res. 2014;7:113-20. 
5. Strober W, Fuss I, Mannon P. The fundamental basis of inflammatory bowel disease. J Clin Invest. 2007;117:514-21.

6. Triantafillidis JK, Nasioulas G, Kosmidis PA. Colorectal cancer and inflammatory bowel disease: epidemiology, risk factors, mechanisms of carcinogenesis and prevention strategies. Anticancer Res. 2009;29:2727-37.

7. Molodecky NA, Soon IS, Rabi DM, Ghali WA, Ferris M, Chernoff G, et al. Increasing incidence and prevalence of the inflammatory bowel diseases with time, based on systematic review. Gastroenterol. 2012;142:46-54.e42.

8. Cosnes J, Gower-Rousseau C, Seksik P, Cortot A. Epidemiology and natural history of inflammatory bowel diseases. Gastroenterol. 2011;140:1785-94.

9. Mehta F. Economic implications of inflammatory bowel disease and its management. Am J Manag Care. 2016;22:s51-60.

10. Colombel JF, Feagan BG, Sandborn WJ, Van Assche G, Robinson AM. Therapeutic drug monitoring of biologics for inflammatory bowel disease. Inflamm Bowel Dis. 2012:18:349-58.

11. Shepela C. The safety of biologic agents in the treatment of inflammatory bowel disease. Minn Med. 2008:91:42-5.

12. Pithadia $A B$, Jain $\mathrm{S}$. Treatment of inflammatory bowel disease (IBD). Pharmacol Rep. 2011:63:629-42.

13. Sharkey KA, Kroese AB. Consequences of intestinal inflammation on the enteric nervous system: neuronal activation induced by inflammatory mediators. Anat Rec. 2001;262:79-90.

14. Furness JB. The enteric nervous system and neurogastroenterology. Nat Rev Gastroenterol Hepatol. 2012;9:286-94.

15. Sanovic S, Lamb DP, Blennerhassett MG. Damage to the enteric nervous system in experimental colitis. Am J Pathol. 1999;155:1051-7.

16. Linden DR, Couvrette JM, Ciolino A, McQuoid C, Blaszyk H, Sharkey KA, et al. Indiscriminate loss of myenteric neurones in the TNBS-inflamed guinea-pig distal colon. Neurogastroenterol Motil. 2005;17:751-60.

17. Dvorak AM, Onderdonk AB, McLeod RS, Monahan-Earley RA, Cullen J, Antonioli DA, et al. Axonal necrosis of enteric autonomic nerves in continent ileal pouches. Possible implications for pathogenesis of Crohn's disease. Ann Surg. 1993;217:260-71.

18. Geboes K, Collins S. Structural abnormalities of the nervous system in Crohn's disease and ulcerative colitis. Neurogastroenterol Motil. 1998:10:189-202.

19. Linden DR, Sharkey KA, Mawe GM. Enhanced excitability of myenteric AH neurones in the inflamed guinea-pig distal colon. J Physiol. 2003;547:589-601.

20. Nurgali K, Nguyen TV, Thacker M, Pontell L, Furness JB. Slow synaptic transmission in myenteric AH neurons from the inflamed guinea pig ileum. Am J Physiol Gastrointest Liver Physiol. 2009;297:G582-93.

21. Nurgali K, Qu Z, Hunne B, Thacker M, Pontell L, Furness JB. Morphological and functional changes in guinea-pig neurons projecting to the ileal mucosa at early stages after inflammatory damage. J Physiol. 2011;589:325-39.

22. Nurgali K, Nguyen TV, Matsuyama H, Thacker M, Robbins HL, Furness JB. Phenotypic changes of morphologically identified guinea-pig myenteric neurons following intestinal inflammation. J Physiol. 2007;583:593-609.

23. Neunlist M, Aubert P, Toquet C, Oreshkova T, Barouk J, Lehur PA, et al. Changes in chemical coding of myenteric neurones in ulcerative colitis. Gut. 2003;52:84-90

24. Winston JH, Li Q, Sarna SK. Paradoxical regulation of ChAT and nNOS expression in animal models of Crohn's colitis and ulcerative colitis. Am J Physiol Gastrointest Liver Physiol. 2013;305:G295-302.

25. Robinson AM, Sakkal S, Park A, Jovanovska V, Payne N, Carbone SE, et al. Mesenchymal stem cells and conditioned medium avert enteric neuropathy and colon dysfunction in guinea pig TNBS-induced colitis. Am J Physiol Gasrointest Liver Physiol. 2014;307:G1115-29.

26. Krauter EM, Strong DS, Brooks EM, Linden DR, Sharkey KA, Mawe GM. Changes in colonic motility and the electrophysiological properties of myenteric neurons persist following recovery from trinitrobenzene sulfonic acid colitis in the guinea pig. Neurogastroenterol Motil. 2007;19:990-1000.

27. Lomax AE, O'Hara JR, Hyland NP, Mawe GM, Sharkey KA. Persistent alterations to enteric neural signaling in the guinea pig colon following the resolution of colitis. Am J Physiol Gastrointest Liver Physiol. 2007;292:G482-91.

28. Wei $X$, Yang $X$, Han ZP, Qu FF, Shao L, Shi YF. Mesenchymal stem cells: a new trend for cell therapy. Acta Pharmacol Sin. 2013;34:747-54.

29. Tanna T, Sachan V. Mesenchymal stem cells: potential in treatment of neurodegenerative diseases. Curr Stem Cell Res Ther. 2014;9:513-21.

30. Farini A, Sitzia C, Erratico S, Meregalli M, Torrente Y. Clinical applications of mesenchymal stem cells in chronic diseases. Stem Cells Int. 2014;2014:306573.
31. Gao F, Chiu SM, Motan DAL, Zhang Z, Chen L, Ji HL, et al. Mesenchymal stem cells and immunomodulation: current status and future prospects. Cell Death Dis. 2016;7:e2062.

32. Zhao Q, Ren H, Han Z. Mesenchymal stem cells: immunomodulatory capability and clinical potential in immune diseases. J Cell Immunother. 2016;2:3-20.

33. Caplan Al, Dennis JE. Mesenchymal stem cells as trophic mediators. J Cell Biochem. 2006:98:1076-84

34. Burdon TJ, Paul A, Noiseux N, Prakash S, Shum-Tim D. Bone marrow stem cell derived paracrine factors for regenerative medicine: current perspectives and therapeutic potential. Bone Marrow Res. 2011;2011:207326.

35. Robinson AM, Miller S, Payne N, Boyd R, Sakkal S, Nurgali K. Neuroprotective potential of mesenchymal stem cell-based therapy in acute stages of TNBS-induced colitis in quinea-pigs. PLoS One. 2015;10:e0139023.

36. Myers TJ, Granero-Molto F, Longobardi L, Li T, Yan Y, Spagnoli A. Mesenchymal stem cells at the intersection of cell and gene therapy. Exp Opin Biol Ther. 2010;10:1663-79.

37. Si YL, Zhao YL, Hao HJ, Fu XB, Han WD. MSCs: Biological characteristics, clinical applications and their outstanding concerns. Ageing Res Rev. 2011;10:93-103.

38. Auletta JJ, Bartholomew AM, Maziarz RT, Deans RJ, Miller RH, Lazarus HM, et al. The potential of mesenchymal stromal cells as a novel cellular therapy for multiple sclerosis. Immunotherapy. 2012;4:529-47.

39. Meyer GP, Wollert KC, Lotz J, Steffens J, Lippolt P, Fichtner S, et al. Intracoronary bone marrow cell transfer after myocardial infarction. Circulation. 2006;113:1287-94.

40. Badillo AT, Peranteau WH, Heaton TE, Quinn C, Flake AW. Murine bone marrow derived stromal progenitor cells fail to prevent or treat acute graft-versus-host disease. Br J Haematol. 2008;141:224-34.

41. Sudres M, Norol F, Trenado A, Grégoire S, Charlotte F, Levacher B, et al. Bone marrow mesenchymal stem cells suppress lymphocyte proliferation in vitro but fail to prevent graft-versus-host disease in mice. J Immunol. 2006:176:7761-7.

42. Nam YS, Kim N, Im KI, Lim JY, Lee ES, Cho SG. Negative impact of bonemarrow-derived mesenchymal stem cells on dextran sulfate sodiuminduced colitis. World J Gastroenterol. 2015;21:2030-9.

43. Kim N, Cho S-G. New strategies for overcoming limitations of mesenchymal stem cell-based immune modulation. Int J Stem Cells. 2015;8:54-68.

44. Zhang J, Huang X, Wang H, Liu X, Zhang T, Wang Y, et al. The challenges and promises of allogeneic mesenchymal stem cells for use as a cell-based therapy. Stem Cell Res Ther. 2015;6:234.

45. Li J, Ezzelarab MB, Cooper DKC. Do mesenchymal stem cells function across species barriers? Relevance for xenotransplantation. Xenotransplantation. 2012;19:273-85.

46. Sharma RR, Pollock K, Hubel A, McKenna D. Mesenchymal stem or stromal cells: a review of clinical applications and manufacturing practices. Transfusion. 2014;54:1418-37.

47. Zappia E, Casazza S, Pedemonte E, Benvenuto F, Bonanni I, Gerdoni E, et al. Mesenchymal stem cells ameliorate experimental autoimmune encephalomyelitis inducing T-cell anergy. Blood. 2005;106:1755-61.

48. Li YP, Paczesny S, Lauret E, Poirault S, Bordigoni P, Mekhloufi F, et al. Human mesenchymal stem cells license adult CD34+ hemopoietic progenitor cells to differentiate into regulatory dendritic cells through activation of the Notch pathway. J Immunol. 2008:180:1598-608.

49. Joo SY, Cho KA, Jung YJ, Kim HS, Park SY, Choi YB, et al. Mesenchymal stromal cells inhibit graft-versus-host disease of mice in a dose-dependent manner. Cytotherapy. 2010;12:361-70

50. Kim H, Kim HY, Choi MR, Hwang S, Nam KH, Kim HC, et al. Dose-dependent efficacy of ALS-human mesenchymal stem cells transplantation into cisterna magna in SOD1-G93A ALS mice. Neurosci Lett. 2010;468:190-4.

51. Gonzalez-Rey E, Anderson P, Gonzalez MA, Rico L, Buscher D, Delgado M. Human adult stem cells derived from adipose tissue protect against experimental colitis and sepsis. Gut. 2009:58:929-39.

52. Hayashi Y, Tsuji S, Tsujii M, Nishida T, Ishii S, lijima H, et al. Topical implantation of mesenchymal stem cells has beneficial effects on healing of experimental colitis in rats. J Pharmacol Exp Ther. 2008;326:523-31.

53. Tanaka F, Tominaga K, Ochi M, Tanigawa T, Watanabe T, Fujiwara Y, et al. Exogenous administration of mesenchymal stem cells ameliorates dextran sulfate sodium-induced colitis via anti-inflammatory action in damaged tissue in rats. Life Sci. 2008;83:771-9. 
54. Yabana T, Arimura Y, Tanaka H, Goto A, Hosokawa M, Nagaishi K, et al. Enhancing epithelial engraftment of rat mesenchymal stem cells restores epithelial barrier integrity. J Pathol. 2009;218:350-9.

55. He XW, He XS, Lian L, Wu XJ, Lan P. Systemic infusion of bone marrowderived mesenchymal stem cells for treatment of experimental colitis in mice. Dig Dis Sci. 2012;57:3136-44.

56. Stavely R, Robinson AM, Miller S, Boyd R, Sakkal S, Nurgali K. Allogeneic guinea pig mesenchymal stem cells ameliorate neurological changes in experimental colitis. Stem Cell Res Ther. 2015;6:263.

57. Stavely R, Robinson AM, Miller S, Boyd R, Sakkal S, Nurgali K. Human adult stem cells derived from adipose tissue and bone marrow attenuate enteric neuropathy in the guinea-pig model of acute colitis. Stem Cell Res Ther. 2015;6:244.

58. Dominici M, Le Blanc K, Mueller I, Slaper-Cortenbach I, Marini F, Krause D, et al. Minimal criteria for defining multipotent mesenchymal stromal cells. The International Society for Cellular Therapy position statement. Cytotherapy. 2006:8:315-7.

59. Pontell L, Castelucci P, Bagyánszki M, Jovic T, Thacker M, Nurgali K, et al. Structural changes in the epithelium of the small intestine and immune cell infiltration of enteric ganglia following acute mucosal damage and local inflammation. Virchows Arch. 2009;455:55-65.

60. García-Olmo D, García-Arranz M, Herreros D, Pascual I, Peiro C, RodríguezMontes JA. A phase I clinical trial of the treatment of Crohn's fistula by adipose mesenchymal stem cell transplantation. Dis Colon Rectum. 2005;48:1416-23.

61. Garcia-Olmo D, Herreros D, Pascual I, Pascual JA, Del-Valle E, Zorrilla J, et al. Expanded adipose-derived stem cells for the treatment of complex perianal fistula: a phase II clinical trial. Dis Colon Rectum. 2009:52:79-86.

62. Duijvestein M, Vos ACW, Roelofs $H$, Wildenberg ME, Wendrich BB, Verspaget $\mathrm{HW}$, et al. Autologous bone marrow-derived mesenchymal stromal cell treatment for refractory luminal Crohn's disease: results of a phase I study. Gut. 2010;59:1662-9.

63. Ciccocioppo R, Bernardo ME, Sgarella A, Maccario R, Avanzini MA, Ubezio C, et al. Autologous bone marrow-derived mesenchymal stromal cells in the treatment of fistulising Crohn's disease. Gut. 2011;60:788-98.

64. Forbes GM, Sturm MJ, Leong RW, Sparrow MP, Segarajasingam D, Cummins $A G$, et al. A phase 2 study of allogeneic mesenchymal stromal cells for luminal Crohn's disease refractory to biologic therapy. Clin Gastroenterol Hepatol. 2014;12:64-71.

65. de la Portilla F, Alba F, García-Olmo D, Herrerías JM, González FX, Galindo A. Expanded allogeneic adipose-derived stem cells (eASCs) for the treatment of complex perianal fistula in Crohn's disease: results from a multicenter phase I/lla clinical trial. Int J Colorectal Dis. 2013;28:313-23.

66. Molendijk I, Bonsing BA, Roelofs H, Peeters KCMJ, Wasser MNJM, Dijkstra G, et al. Allogeneic bone marrow-derived mesenchymal stromal cells promote healing of refractory perianal fistulas in patients with Crohn's disease. Gastroenterol. 2015:149:918-27.

67. Cho YB, Lee WY, Park KJ, Kim M, Yoo HW, Yu CS. Autologous adipose tissuederived stem cells for the treatment of Crohn's fistula: A phase I clinical study. Cell Transplant. 2013;22:279-85.

68. Lee WY, Park KJ, Cho YB, Yoon SN, Song KH, Kim DS, et al. Autologous adipose tissue-derived stem cells treatment demonstrated favorable and sustainable therapeutic effect for Crohn's fistula. Stem Cells. 2013;31:2575-81.

69. Tanaka H, Arimura Y, Yabana T, Goto A, Hosokawa M, Nagaishi K, et al. Myogenic lineage differentiated mesenchymal stem cells enhance recovery from dextran sulfate sodium-induced colitis in the rat. J Gastroenterol. 2011;46:143-52

70. Castelo-Branco MTL, Soares IDP, Lopes DV, Buongusto F, Martinusso CA, do Rosario A, et al. Intraperitoneal but not intravenous cryopreserved mesenchymal stromal cells home to the inflamed colon and ameliorate experimental colitis. PLoS One. 2012;7:e33360

71. Fawzy SA, El-din Abo-Elnou RK, Abd-El-Maksoud El-Deeb DF, Yousry AbdElkader MM. The possible role of mesenchymal stem cells therapy in the repair of experimentally induced colitis in male albino rats. Int J Stem Cells. 2013;6:92-103

72. Chen QQ, Yan L, Wang CZ, Wang WH, Shi H, Su BB, et al. Mesenchymal stem cells alleviate TNBS-induced colitis by modulating inflammatory and autoimmune responses. World J Gastroenterol. 2013;19:4702-17.

73. Wang C, Chen J, Sun L, Liu Y. TGF-beta signaling-dependent alleviation of dextran sulfate sodium-induced colitis by mesenchymal stem cell transplantation. Mol Biol Rep. 2014;41:4977-83.
74. Liu W, Zhang S, Gu S, Sang L, Dai C. Mesenchymal stem cells recruit macrophages to alleviate experimental colitis through TGFß1. Cell Physiol Biochem. 2015;35:858-65.

75. Zhang Q, Shi S, Liu Y, Uyanne J, Shi Y, Shi S, et al. Mesenchymal stem cells derived from human gingiva are capable of immunomodulatory functions and ameliorate inflammation-related tissue destruction in experimental colitis. J Immunol. 2009;183:7787-98.

76. Duijvestein M, Wildenberg ME, Welling MM, Hennink S, Molendijk I, van Zuylen $V L$, et al. Pretreatment with interferon- $\gamma$ enhances the therapeutic activity of mesenchymal stromal cells in animal models of colitis. Stem Cells. 2011:29:1549-58.

77. Ando Y, Inaba M, Sakaguchi Y, Tsuda M, Quan GK, Omae M, et al. Subcutaneous adipose tissue-derived stem cells facilitate colonic mucosal recovery from 2,4,6-trinitrobenzene sulfonic acid (TNBS)-induced colitis in rats. Inflamm Bowel Dis. 2008;14:826-38.

78. Gonzalez MA, Gonzalez-Rey E, Rico L, Buscher D, Delgado M. Adiposederived mesenchymal stem cells alleviate experimental colitis by inhibiting inflammatory and autoimmune responses. Gastroenterol. 2009;136:978-89.

79. Anderson P, Souza-Moreira L, Morell M, Caro M, O'Valle F, Gonzalez-Rey E, et al. Adipose-derived mesenchymal stromal cells induce immunomodulatory macrophages which protect from experimental colitis and sepsis. Gut. 2013;62:1131-41.

80. Liu X, Zuo D, Fan H, Tang Q, Shou Z, Cao D, et al. Over-expression of CXCR4 on mesenchymal stem cells protect against experimental colitis via immunomodulatory functions in impaired tissue. J Mol Histol. 2014;45:181-93.

81. Liang L, Dong C, Chen X, Fang Z, Xu J, Liu M, et al. Human umbilical cord mesenchymal stem cells ameliorate mice trinitrobenzene sulfonic acid (TNBS)-induced colitis. Cell Transplant. 2011:20:1395-408.

82. Kim HS, Shin TH, Lee BC, Yu KR, Seo Y, Lee S, et al. Human umbilical cord blood mesenchymal stem cells reduce colitis in mice by activating NOD2 signaling to COX2. Gastroenterol. 2013;145:1392-403.

83. Chao K, Zhang S, Qiu Y, Chen X, Zhang X, Cai C, et al. Human umbilical cord-derived mesenchymal stem cells protect against experimental colitis via CD5+ B regulatory cells. Stem Cell Res Ther. 2016;7:109.

84. Mendicino M, Bailey Alexander M, Wonnacott K, Puri Raj K, Bauer SR. MSCbased product characterization for clinical trials: an FDA perspective. Cell Stem Cell. 2014;14:141-5.

85. Wieczorek $G$, Steinhoff $C$, Schulz $R$, Scheller $M$, Vingron $M$, Ropers $H H$, et al. Gene expression profile of mouse bone marrow stromal cells determined by cDNA microarray analysis. Cell Tissue Res. 2003;311:227-37.

86. Zavan B, Giorgi C, Bagnara GP, Vindigni V, Abatangelo G, Cortivo R. Osteogenic and chondrogenic differentiation: comparison of human and rat bone marrow mesenchymal stem cells cultured into polymeric scaffolds. Eur J Histochem. 2007:51:1-8.

87. Scuteri A, Donzelli E, Foudah D, Caldara C, Redondo J, D'Amico G, et al. Mesengenic differentiation: comparison of human and rat bone marrow mesenchymal stem cells. Int J Stem Cells. 2014;7:127-34.

88. Foudah D, Redaelli S, Donzelli E, Bentivegna A, Miloso M, Dalprà L, et al. Monitoring the genomic stability of in vitro cultured rat bone-marrowderived mesenchymal stem cells. Chromosome Res. 2009;17:1025-39.

89. Redaelli S, Bentivegna A, Foudah D, Miloso M, Redondo J, Riva G, et al. From cytogenomic to epigenomic profiles: monitoring the biologic behavior of in vitro cultured human bone marrow mesenchymal stem cells. Stem Cell Res Ther. 2012;3:47.

90. Martínez-Lorenzo MJ, Royo-Cañas M, Alegre-Aguarón E, Desportes P, Castiella T, García-Álvarez F, et al. Phenotype and chondrogenic differentiation of mesenchymal cells from adipose tissue of different species. J Orthop Res. 2009;27:1499-507.

91. Ren G, Su J, Zhang L, Zhao X, Ling W, L'Huillie A, et al. Species variation in the mechanisms of mesenchymal stem cell-mediated immunosuppression. Stem Cells. 2009:27:1954-62.

92. Jones E, Schäfer R. Biological differences between native and cultured mesenchymal stem cells: implications for therapies. Methods Mol Biol 2015:1235:105-20

93. Hass R, Kasper C, Böhm S, Jacobs R. Different populations and sources of human mesenchymal stem cells (MSC): A comparison of adult and neonatal tissue-derived MSC. Cell Commun Signal. 2011;9:12.

94. Roemeling-van Rhijn M, Khairoun M, Korevaar SS, Lievers E, Leuning DG, ljzermans JNM, et al. Human bone marrow and adipose tissue-derived mesenchymal stromal cells are immunosuppressive in vitro and in a humanized allograft rejection model. J Stem Cell Res Ther. 2013;6:20780. 
95. Antunes MA, Laffey JG, Pelosi P, Rocco PR. Mesenchymal stem cell trials for pulmonary diseases. J Cell Biochem. 2014;115:1023-32.

96. Elman JS, Li M, Wang F, Gimble JM, Parekkadan B. A comparison of adipose and bone marrow-derived mesenchymal stromal cell secreted factors in the treatment of systemic inflammation. J Inflamm. 2014;11:1-8.

97. Karp JM, Teo GSL. Mesenchymal stem cell homing: the devil is in the details. Cell Stem Cell. 2009:4:206-16.

98. Bernardo ME, Fibbe WE. Mesenchymal stromal cells: sensors and switchers of inflammation. Cell Stem Cell. 2013;13:392-402

99. Wang $Y$, Chen $X$, Cao W, Shi Y. Plasticity of mesenchymal stem cells in immunomodulation: pathological and therapeutic implications. Nat Immunol. 2014;15:1009-16.

100. Jacobs SA, Roobrouck VD, Verfaillie CM, Van Gool SW. Immunological characteristics of human mesenchymal stem cells and multipotent adult progenitor cells. Immunol Cell Biol. 2013;91:32-9.

101. Machado CV, Telles PD, Nascimento IL. Immunological characteristics of mesenchymal stem cells. Rev Bras Hematol Hemoter. 2013;35:62-7.

102. Hu X, Wang J, Chen J, Luo R, He A, Xie X, et al. Optimal temporal delivery of bone marrow mesenchymal stem cells in rats with myocardial infarction. Eur J Cardiothorac Surg. 2007;31:438-43.

103. Ferrante $M$, de Hertogh $G$, Hlavaty $T$, D'Haens $G$, Penninckx F, D'Hoore A et al. The value of myenteric plexitis to predict early postoperative Crohn's disease recurrence. Gastroenterol. 2006;130:1595-606.

104. Villanacci V, Bassotti G, Nascimbeni R, Antonelli E, Cadei M, Fisogni S, et al. Enteric nervous system abnormalities in inflammatory bowel diseases. Neurogastroenterol Motil. 2008;20:1009-16.

105. Sokol H, Polin V, Lavergne-Slove A, Panis Y, Treton X, Dray X, et al. Plexitis as a predictive factor of early postoperative clinical recurrence in Crohn's disease. Gut. 2009;58:1218-25.

106. Mawe GM. Colitis-induced neuroplasticity disrupts motility in the inflamed and post-inflamed colon. J Clin Invest. 2015;125:949-55.

107. Crop MJ, Baan CC, Korevaar SS, ljzermans JNM, Pescatori M, Stubbs AP, et al. Inflammatory conditions affect gene expression and function of human adipose tissue-derived mesenchymal stem cells. Clin Exp Immunol. 2010;162:474-86.

108. Chen L, Tredget EE, Wu PYG, Wu Y. Paracrine factors of mesenchymal stem cells recruit macrophages and endothelial lineage cells and enhance wound healing. PLoS One. 2008;3:e1886.

109. Ankrum J, Karp JM. Mesenchymal stem cell therapy: two steps forward, one step back. Trends Mol Med. 2010;16:203-9.

110. Parekkadan B, Milwid JM. Mesenchymal stem cells as therapeutics. Annu Rev Biomed Eng. 2010;12:87-117.

111. Sémont A, Demarquay C, Bessout R, Durand C, Benderitter M, Mathieu N. Mesenchymal stem cell therapy stimulates endogenous host progenitor cells to improve colonic epithelial regeneration. PLoS One. 2013;8:e70170.

112. Yang J, Liu XX, Fan H, Tang Q, Shou ZX, Zuo DM, et al. Extracellular vesicles derived from bone marrow mesenchymal stem cells protect against experimental colitis via attenuating colon inflammation, oxidative stress and apoptosis. PLoS One. 2015;10:e0140551.

113. Forte D, Ciciarello M, Valerii MC, De Fazio L, Cavazza E, Giordano R, et al. Human cord blood-derived platelet lysate enhances the therapeutic activity of adipose-derived mesenchymal stromal cells isolated from Crohn's disease patients in a mouse model of colitis. Stem Cell Res Ther. 2015;6:170.

114. Zuo D, Tang Q, Fan H, Shou Z, Liu X, Cao D, et al. Modulation of nuclear factor-kappaB-mediated pro-inflammatory response is associated with exogenous administration of bone marrow-derived mesenchymal stem cells for treatment of experimental colitis. Mol Med Rep. 2015;11:2741-8.

115. Sala E, Genua M, Petti L, Anselmo A, Arena V, Cibella J, et al. Mesenchymal stem cells reduce colitis in mice via release of TSG6, independently of their localization to the intestine. Gastroenterol. 2015;149:163-76.e20.

116. Ladak A, Olson J, Tredget EE, Gordon T. Differentiation of mesenchymal stem cells to support peripheral nerve regeneration in a rat model. Exp Neurol. 2011;228:242-52

117. Petrova ES. Injured nerve regeneration using cell-based therapies: current challenges. Acta Nat. 2015;7:38-47.

118. Wei X, Zhao L, Zhong J, Gu H, Feng D, Johnstone BH, et al. Adipose stromal cells-secreted neuroprotective media against neuronal apoptosis. Neurosci Lett. 2009;462:76-9.

119. Suzuki M, McHugh J, Tork C, Shelley B, Hayes A, Bellantuono I, et al. Direct muscle delivery of GDNF with human mesenchymal stem cells improves motor neuron survival and function in a rat model of familial ALS. Mol Ther. 2008;16:2002-10.
120. Marconi S, Bonaconsa M, Scambi I, Squintani GM, Rui W, Turano E, et al. Systemic treatment with adipose-derived mesenchymal stem cells ameliorates clinical and pathological features in the amyotrophic lateral sclerosis murine model. Neuroscience. 2013;248:333-43.

121. Kim YJ, Park HJ, Lee G, Bang OY, Ahn YH, Joe E, et al. Neuroprotective effects of human mesenchymal stem cells on dopaminergic neurons through anti-inflammatory action. Glia. 2009;57:13-23.

122. Hogaboam CM, Jacobson K, Collins SM, Blennerhassett MG. The selective beneficial effects of nitric oxide inhibition in experimental colitis. Am J Physiol. 1995;268:G673-84.

123. Boyer L, Ghoreishi M, Templeman V, Vallance BA, Buchan AM, Jevon G, et al. Myenteric plexus injury and apoptosis in experimental colitis. Auton Neurosci. 2005;117:41-53.

124. Poli E, Lazzaretti M, Grandi D, Pozzoli C, Coruzzi G. Morphological and functional alterations of the myenteric plexus in rats with TNBS-induced colitis. Neurochem Res. 2001;26:1085-93.

125. Belai A, Boulos PB, Robson T, Burnstock G. Neurochemical coding in the small intestine of patients with Crohn's disease. Gut. 1997;40:767-74.

126. Boyer L, Sidpra D, Jevon G, Buchan AM, Jacobson K. Differential responses of VIPergic and nitrergic neurons in paediatric patients with Crohn's disease. Auton Neurosci. 2007;134:106-14.

127. Hofstetter CP, Schwarz EJ, Hess D, Widenfalk J, El Manira A, Prockop DJ, et al. Marrow stromal cells form guiding strands in the injured spinal cord and promote recovery. Proc Natl Acad Sci U S A. 2002;99:2199-204.

128. Zhang J, Li Y, Lu M, Cui Y, Chen J, Noffsinger L, et al. Bone marrow stromal cells reduce axonal loss in experimental autoimmune encephalomyelitis mice. J Neurosci Res. 2006;84:587-95.

129. Ohtaki H, Ylostalo JH, Foraker JE, Robinson AP, Reger RL, Shioda S, et al. Stem/progenitor cells from bone marrow decrease neuronal death in global ischemia by modulation of inflammatory/immune responses. Proc Natl Acad Sci U S A. 2008;105:14638-43.

130. Bang OY, Lee JS, Lee PH, Lee G. Autologous mesenchymal stem cell transplantation in stroke patients. Ann Neurol. 2005:57:874-82.

131. Freedman MS, Bar-Or A, Atkins HL, Karussis D, Frassoni F, Lazarus H, et al. The therapeutic potential of mesenchymal stem cell transplantation as a treatment for multiple sclerosis: consensus report of the International MSCT Study Group. Mult Scler. 2010;16:503-10.

132. Uccelli A, Moretta L, Pistoia V. Mesenchymal stem cells in health and disease. Nat Rev Immunol. 2008;8:726-36.

133. Salgado AJ, Reis RL, Sousa NJ, Gimble JM. Adipose tissue derived stem cells secretome: soluble factors and their roles in regenerative medicine. Curr Stem Cell Res Ther. 2010;5:103-10.

134. Singer NG, Caplan Al. Mesenchymal stem cells: mechanisms of inflammation. Annu Rev Pathol. 2011:6:457-78.

135. Skalnikova H, Motlik J, Gadher SJ, Kovarova H. Mapping of the secretome of primary isolates of mammalian cells, stem cells and derived cell lines. Proteomics. 2011;11:691-708

136. Marino R, Martinez C, Boyd K, Dominici M, Hofmann TJ, Horwitz EM Transplantable marrow osteoprogenitors engraft in discrete saturable sites in the marrow microenvironment. Exp Hematol. 2008:36:360-8.

137. Audet J, Miller CL, Rose-John S, Piret JM, Eaves CJ. Distinct role of gp130 activation in promoting self-renewal divisions by mitogenically stimulated murine hematopoietic stem cells. Proc Natl Acad Sci U S A. 2001;98:1757-62.

138. Audet J, Miller CL, Eaves CJ, Piret JM. Common and distinct features of cytokine effects on hematopoietic stem and progenitor cells revealed by dose-response surface analysis. Biotechnol Bioeng. 2002;80:393-404.

139. Viswanathan S, Benatar T, Rose-John S, Lauffenburger DA, Zandstra PW. Ligand/receptor signaling threshold (LIST) model accounts for gp130mediated embryonic stem cell self-renewal responses to LIF and HIL-6. Stem Cells. 2002;20:119-38. 